\title{
Dry reforming of glycerol over Rh-based ceria and zirconia catalysts: New insights on catalyst activity and stability
}

\author{
Pelin Su Bulutoglu ${ }^{\mathrm{a}, 1}$, Zafer Say ${ }^{\mathrm{b}, 1}$, Selin Bac ${ }^{\mathrm{a}}$, Emrah Ozensoy ${ }^{\mathrm{b}, \mathrm{c}, *}$, Ahmet K. Avci ${ }^{\mathrm{a}, *}$

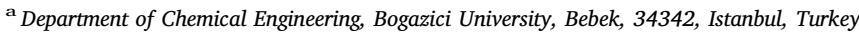 \\ ${ }^{\mathrm{b}}$ Bilkent University, Department of Chemistry, 06800, Ankara, Turkey \\ ' UNAM-National Nanotechnology Center, Bilkent University, 06800, Ankara, Turkey
}

\section{A R T I C L E I N F O}

\section{Keywords:}

Glycerol

Carbon dioxide

Dry reforming

Synthesis gas

Rhodium

\begin{abstract}
A B S T R A C T
Effects of reaction temperature and feed composition on reactant conversion, product distribution and catalytic stability were investigated on syngas production by reforming of glycerol, a renewable waste, with $\mathrm{CO}_{2}$ on $\mathrm{Rh} /$ $\mathrm{ZrO}_{2}$ and $\mathrm{Rh} / \mathrm{CeO}_{2}$ catalysts. For the first time in the literature, fresh and spent catalysts were characterized by in-situ FTIR, Raman spectroscopy, transmission electron microscopy and energy dispersive X-ray analysis techniques in order to unravel novel insights regarding the molecular-level origins of catalytic deactivation and aging under the conditions of glycerol dry reforming. Both catalysts revealed increased glycerol conversions with increasing temperature, where the magnitude of response became particularly notable above 650 and $700{ }^{\circ} \mathrm{C}$ on $\mathrm{Rh} / \mathrm{ZrO}_{2}$ and $\mathrm{Rh} / \mathrm{CeO}_{2}$, respectively. In accordance with thermodynamic predictions, $\mathrm{CO}_{2}$ transformation occurred only above $700{ }^{\circ} \mathrm{C}$. Syngas was obtained at $\mathrm{H}_{2} / \mathrm{CO} \sim 0.8$, very close to the ideal composition for FischerTropsch synthesis, and carbon formation was minimized with increasing temperature. Glycerol conversion decreased monotonically, whereas, after an initial increase, $\mathrm{CO}_{2}$ conversion remained constant upon increasing $\mathrm{CO}_{2} /$ glycerol ratio $\left(\mathrm{CO}_{2} / \mathrm{G}\right)$ from 1 to 4 . In alignment with the slightly higher specific surface area of and smaller average Rh-particle size on $\mathrm{ZrO}_{2}, \mathrm{Rh} / \mathrm{ZrO}_{2}$ exhibited higher conversions and syngas yields than that of $\mathrm{Rh} / \mathrm{CeO}$. Current characterization studies indicated that $\mathrm{Rh} / \mathrm{CeO}_{2}$ revealed strong metal-support interaction, through which $\mathrm{CeO}_{2}$ seemed to encapsulate $\mathrm{Rh}$ nanoparticles and partially suppressed the catalytic activity of Rh sites. However, such interactions also seemed to improve the stability of $\mathrm{Rh} / \mathrm{CeO}_{2}$, rendering its activity loss to stay below that of $\mathrm{Rh} / \mathrm{ZrO}_{2}$ after $72 \mathrm{~h}$ time-on-stream testing at $750{ }^{\circ} \mathrm{C}$ and for $\mathrm{CO}_{2} / \mathrm{G}=4$. Enhanced stability in the presence of $\mathrm{CeO}_{2}$ was associated with the inhibition of coking of the catalyst surface by the mobile oxygen species and creation of oxygen vacancies on ceria domains. Deactivation of $\mathrm{Rh} / \mathrm{ZrO}_{2}$ was attributed to the sintering of $\mathrm{Rh}$ nanoparticles and carbon formation.
\end{abstract}

\section{Introduction}

A majority of the world's existing energy demand is met by fossil fuels such as crude oil, coal and natural gas, all of which accounts for more than $80 \%$ of total energy consumption [1]. However, increasing costs of exploration and production of fossil fuels together with the environmental and societal impacts of global warming caused by accumulation of $\mathrm{CO}_{2}$, accelerated efforts towards research, development and commercial use of renewable fuels and energy conversion technologies. Among a number of renewable fuels, biodiesel is receiving increased attention as it can be blended with the crude-oil based diesel without losing its compatibility with the existing diesel engines [2].
Since 2005 , biodiesel market grew by $\sim 23 \%$ per year, which corresponds to a seven-fold market expansion in the last decade [3].

Biodiesel production is carried out by transesterification of animalbased or vegetable oils with methanol or ethanol. In this process, one mole of glycerol is produced as a side product for every three moles of biodiesel [4,5]. This stoichiometry, however, leads to a significant surplus of glycerol. It is predicted that cumulative glycerol supply will be $\sim 3 \times 10^{6}$ ton by 2020 , whereas the demand will remain below $\sim 5 \times 10^{5}$ ton/year [4]. Along these lines, production costs of biodiesel can be lowered by catalytic valorization of excess glycerol into valueadded products such as syngas (i.e. synthesis gas), which is the raw material of key commodities such as synthetic fuels, methanol and

\footnotetext{
* Corresponding authors at: Department of Chemical Engineering, Bogazici University, Bebek, 34342, Istanbul, Turkey and Bilkent University, Department of Chemistry, 06800, Ankara, Turkey.

E-mail addresses: ozensoy@fen.bilkent.edu.tr (E. Ozensoy), avciahme@boun.edu.tr (A.K. Avci).

1 These authors contributed equally to the work.
} 
dimethyl ether [6].

Steam reforming is the main route to transform glycerol into a hydrogen-rich gas mixture. As summarized in various comprehensive reviews [4,6-8], glycerol steam reforming (GSR) has been investigated extensively in various aspects ranging from catalyst development at fundamental levels to the testing of different reactor configurations. Steam reforming generates syngas with low $\mathrm{CO}$ content (i.e. $\mathrm{H}_{2} / \mathrm{CO}$ $>2$ ), rendering it disadvantageous in the production of long chain hydrocarbons via Fischer-Tropsch (FT) synthesis [9-11]. Reforming of glycerol with $\mathrm{CO}_{2}$, on the other hand, is capable of not only delivering syngas with molar $\mathrm{H}_{2} / \mathrm{CO}$ ratios close to 1 , but also satisfying the feed conditions for FT synthesis to obtain long chain hydrocarbons [9,12]. Moreover, dry reforming offers the advantage of obtaining syngas from molecules which can cause serious economic and environmental penalties. These benefits make the dry reforming route a promising option for glycerol valorization.

Glycerol dry reforming (GDR) is an endothermic process where one mole of glycerol reacts with one mole of $\mathrm{CO}_{2}$ to produce $\mathrm{H}_{2}, \mathrm{CO}$ and $\mathrm{H}_{2} \mathrm{O}$ through the following overall reaction:

$\mathrm{C}_{3} \mathrm{H}_{8} \mathrm{O}_{3}+\mathrm{CO}_{2} \rightarrow 4 \mathrm{CO}+3 \mathrm{H}_{2}+\mathrm{H}_{2} \mathrm{O} \quad \Delta H^{\circ}=292 \mathrm{~kJ} / \mathrm{mol}$

In dry reforming conditions that involve temperatures in excess of $500{ }^{\circ} \mathrm{C}$ and presence of $\mathrm{CO}_{2}$ in the feed, reverse water gas shift (RWGS Reaction 2) affects the product distribution [13]. Therefore, Reaction 1 can be envisioned as the combination of RWGS and glycerol decomposition (Reaction 3):

$\mathrm{CO}_{2}+\mathrm{H}_{2} \rightarrow \mathrm{CO}+\mathrm{H}_{2} \mathrm{O} \quad \Delta H^{\circ}=41 \mathrm{~kJ} / \mathrm{mol}$

$\mathrm{C}_{3} \mathrm{H}_{8} \mathrm{O}_{3} \rightarrow 3 \mathrm{CO}+4 \mathrm{H}_{2} \quad \Delta H^{\circ}=251 \mathrm{~kJ} / \mathrm{mol}$

In addition to Reaction 3, decomposition of glycerol involves a series of dehydration and dehydrogenation reactions which lead to the production of various species such as methane, ethane, ethylene, acetaldehyde, acrolein, acetone, methanol, ethanol and acetic acid [14]. These species can eventually be converted into coke via homogeneous/heterogeneous thermal cracking reactions. Other possible side reactions are steam and dry reforming of methane (Reactions 4 and 5) and of higher hydrocarbons, and coke gasification (Reactions 6-8):

$$
\begin{aligned}
& \mathrm{CH}_{4}+\mathrm{H}_{2} \mathrm{O} \rightarrow \mathrm{CO}+3 \mathrm{H}_{2} \quad \Delta H^{\circ}=206 \mathrm{~kJ} / \mathrm{mol} \\
& \mathrm{CH}_{4}+\mathrm{CO}_{2} \rightarrow 2 \mathrm{CO}+2 \mathrm{H}_{2} \quad \Delta H^{\circ}=247 \mathrm{~kJ} / \mathrm{mol} \\
& \mathrm{C}(\mathrm{s})+\mathrm{H}_{2} \mathrm{O} \rightarrow \mathrm{CO}+\mathrm{H}_{2} \quad \Delta H^{\circ}=131 \mathrm{~kJ} / \mathrm{mol} \\
& \mathrm{C}(\mathrm{s})+2 \mathrm{H}_{2} \mathrm{O} \rightarrow \mathrm{CO}_{2}+2 \mathrm{H}_{2} \quad \Delta H^{\circ}=90 \mathrm{~kJ} / \mathrm{mol} \\
& \mathrm{C}(\mathrm{s})+\mathrm{CO}_{2} \rightarrow 2 \mathrm{CO} \Delta H^{\circ}=172 \mathrm{~kJ} / \mathrm{mol}
\end{aligned}
$$

Endothermic nature of GDR requires temperatures above $\sim 500{ }^{\circ} \mathrm{C}$, where the reaction is thermodynamically favored [12,15,16]. Wang et al. [15] reported that $727^{\circ} \mathrm{C}$ and molar inlet $\mathrm{CO}_{2} / \mathrm{G}$ of 1 were optimum thermodynamic conditions for maximizing $\mathrm{H}_{2}$ yield, and showed that molar $\mathrm{H}_{2} / \mathrm{CO}$ ratios produced by GDR changed between 1 and 2.15 by varying the temperature between $500-700{ }^{\circ} \mathrm{C}$ and $\mathrm{CO}_{2} / \mathrm{G}$ ratios within 1-5. They also mentioned that coke formation decreased with increasing temperature. Thermodynamically, coke formation became insignificant above $677^{\circ} \mathrm{C}$ at $\mathrm{CO}_{2} / \mathrm{G}=1$ [15].

GDR has become the focus of experimental studies only recently and the available information in the literature regarding its catalysis is rather scarce. Siew et al. [17-20] studied GDR over La-promoted Ni/ $\mathrm{Al}_{2} \mathrm{O}_{3}$ catalysts at temperatures between $650-850{ }^{\circ} \mathrm{C}$ and $\mathrm{CO}_{2} / \mathrm{G}=0-5$. The authors concluded that La promotion (i) provided better metal dispersion (i.e. a finer crystallite size and higher BET specific surface area), (ii) significantly reduced carbon deposition, and (iii) reduced deactivation rate as quantified by the $72 \mathrm{~h}$ time-on-stream stability tests carried out at $750{ }^{\circ} \mathrm{C}$ to give an average glycerol conversion of $90 \%$. They also reported that presence of $\mathrm{CO}_{2}$ was essential in reducing carbon deposition through the gasification reactions. Lee et al. [21,22] investigated GDR over Ni-based catalysts supported on cement clinker (CC), a material composed mainly of $\mathrm{CaO}$ and $\mathrm{MgO}$, with the intention of utilizing $\mathrm{CO}_{2}$ emitted during cement production. They concluded that use of CC facilitated the suppression of carbon formation. Furthermore, increasing Ni loading from $5 \mathrm{wt} . \%$ to $20 \mathrm{wt} . \%$ improved BET specific surface area from 0.6 to $18 \mathrm{~m}^{2} / \mathrm{g}$. The authors also reported $\mathrm{H}_{2} /$ CO ratios below 2 and glycerol conversions up to $\sim 80 \%$ upon reaction at $750{ }^{\circ} \mathrm{C}$ and $\mathrm{CO}_{2} / \mathrm{G}$ of 1.67 , which were claimed to be optimum for the 20 wt.\% Ni loaded catalyst. Arif et al. [23] compared the activities of $\mathrm{CaO}$ and $\mathrm{ZrO}_{2}$ supported Ni catalysts with different metal loadings in GDR. It was reported that at $700{ }^{\circ} \mathrm{C}$ and for $\mathrm{CO}_{2} / \mathrm{G}$ ratio of $1, \mathrm{Ni} / \mathrm{CaO}$ catalyst gave a $\mathrm{H}_{2}$ yield and a glycerol conversion higher than those obtained over $\mathrm{Ni} / \mathrm{ZrO}_{2}$. Superiority of $\mathrm{CaO}$ supported samples over $\mathrm{ZrO}_{2}$ supported ones was attributed to the higher metal dispersion and smaller $\mathrm{NiO}$ crystallite size over $\mathrm{CaO}$ as revealed by XRD analysis. Harun et al. [24] studied 0-5\% Ag-promoted $15 \% \mathrm{Ni} / \mathrm{SiO}_{2}$ catalysts for GDR. It was revealed by XRD analysis that addition of $\mathrm{Ag}$ did not change the metal crystallite size significantly, but improved $\mathrm{H}_{2}$ yield and glycerol conversion. Carbonaceous deposits were found to exist on the catalysts upon SEM analysis of the spent samples.

As summarized above, a comprehensive molecular-level fundamental understanding of GDR catalysis is clearly missing. Moreover, detailed information regarding the effect of reaction parameters on $\mathrm{CO}_{2}$ conversion, yield and syngas composition is not available. Thus, in the current work, we follow a systematic experimental approach in order to address some of these issues and combine catalytic activity/selectivity studies with detailed molecular-level in-situ/ex-situ spectroscopic/imaging investigations in an attempt to obtain new structure-functionality relationships about GDR. We focus on Rh-based catalysts supported on $\mathrm{ZrO}_{2}$ and $\mathrm{CeO}_{2}$. Although Rh-based catalysts were reported to exhibit superior activity and stability features in dry reforming of various hydrocarbons [25-29], no such catalysts exist in the literature for GDR process. As for the supports, both $\mathrm{ZrO}_{2}$ and $\mathrm{CeO}_{2}$ are known as promising materials for dry reforming reactions due to their advantageous oxygen transfer properties. Oxygen vacancies on $\mathrm{ZrO}_{2}$ were reported to help dissociation of $\mathrm{CO}_{2}$ into $\mathrm{CO}$ and $\mathrm{O}$, which in turn, facilitates the oxidation of the surface carbon species [30-32]. $\mathrm{CeO}_{2}$ is known to have a high oxygen storage capacity, which can create an oxygen reservoir enabling gasification of coke $[33,34]$. In the light of these points, $\mathrm{Rh} /$ $\mathrm{ZrO}_{2}$ and $\mathrm{Rh} / \mathrm{CeO}_{2}$ can be envisioned as promising novel catalysts that can be investigated in GDR process. Along these lines, in the current study, we report Rh-based GDR catalysts which outperform the existing Ni-based ones [17-24] in terms of activity and stability. Furthermore, through in-situ/ex-situ spectroscopic/imaging experiments, for the first time in the literature, we provide valuable insights regarding the origins of catalytic activity, stability, aging and sintering in GDR reaction.

\section{Experimental}

\subsection{Catalyst synthesis and pretreatment}

Catalysts, 1 wt.\% Rh/CeO 2 (RhCe) and 1 wt.\% Rh/ZrO ${ }_{2}$ (RhZr), were prepared by conventional incipient wetness impregnation method. The first step in synthesizing RhCe was the preparation of the support. For this purpose, $\mathrm{Ce}\left(\mathrm{NO}_{3}\right)_{3} \cdot 6 \mathrm{H}_{2} \mathrm{O}$ (purity: $99.99 \%$, SigmaAldrich) was first calcined in air at $600{ }^{\circ} \mathrm{C}$ for $4 \mathrm{~h}$ for achieving thermal decomposition to $\mathrm{CeO}_{2}$ [35]. The resulting material was calcined at $800{ }^{\circ} \mathrm{C}$ in a muffle furnace under air atmosphere for $4 \mathrm{~h}$ in order to enhance thermal stability (i.e. for preventing its sintering during reaction conditions). A necessary amount $\left(7 \times 10^{-2} \mathrm{ml} / \mathrm{g}\right.$ catalyst) of liquid Rh-precursor ( $\mathrm{Rh}\left(\mathrm{NO}_{3}\right)_{3}$, purity: $10 \%(\mathrm{w} / \mathrm{w}) \mathrm{Rh}$ in $>5 \mathrm{wt} . \% \mathrm{HNO}_{3}$ solution, Sigma-Aldrich) was dissolved in deionized water and this aqueous precursor solution was impregnated onto the $\mathrm{CeO}_{2}$ support with a particle size range of $2.5-3.5 \times 10^{-4} \mathrm{~m}$ by means of a peristaltic pump under vacuum. The resulting slurry was dried overnight in an oven at 


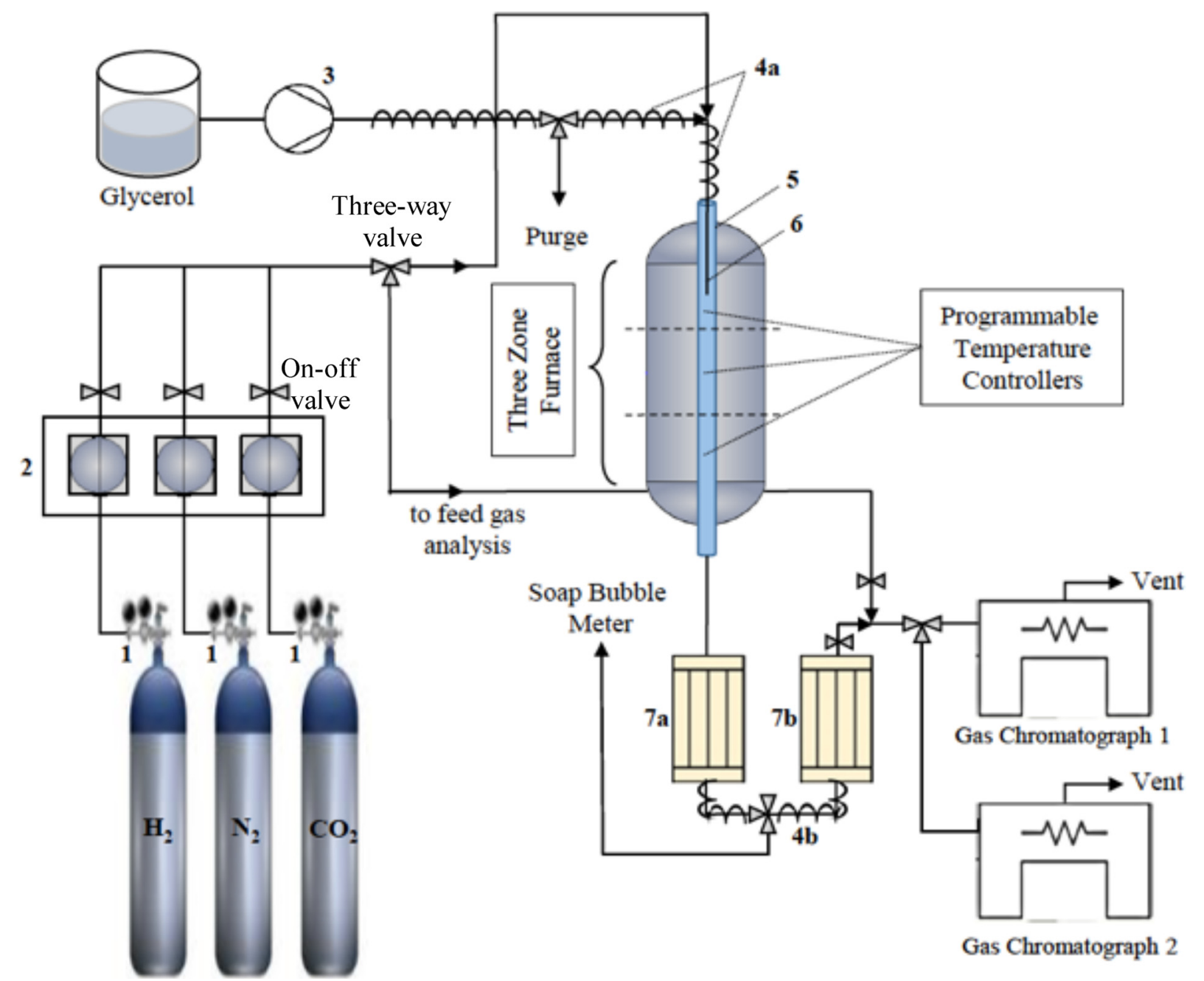


Injection nozzle, 7. Dewar flasks including the cold traps.

$110{ }^{\circ} \mathrm{C}$ and then calcined in a muffle furnace at $800^{\circ} \mathrm{C}$ for $4 \mathrm{~h}$. An identical protocol was used for the synthesis of RhZr. Prior to its use in impregnation, the zirconia support $\left(\mathrm{ZrO}_{2}\right.$, purity: $99 \%$, Alfa Aesar) was brought to a particle size range of $2.5-3.5 \times 10^{-4} \mathrm{~m}$ and calcined at $800^{\circ} \mathrm{C}$ for $4 \mathrm{~h}$. Before reaction tests, the catalysts were reduced in-situ at $800{ }^{\circ} \mathrm{C}$ [36] for $2 \mathrm{~h}$ under $40 \mathrm{Nml} / \mathrm{min} \mathrm{H}_{2}$ (purity $>99.99 \%$, Linde $\mathrm{GmbH}$ ) flow measured by a Brooks 5850E Series Mass Flow Controller.

\subsection{Catalyst characterization}

\subsection{1. $N_{2}$ physisorption}

BET isotherms were obtained by using a Quantachrome Nova 2200e automated gas adsorption system with liquid nitrogen at a temperature of $-196^{\circ} \mathrm{C}$. Specific surface areas of the pure support materials (i.e. $\mathrm{ZrO}_{2}$ and $\mathrm{CeO}_{2}$ ) calcined at $800^{\circ} \mathrm{C}$ for $4 \mathrm{~h}$ were determined via multipoint BET analysis. Pore sizes and pore diameters were calculated using the BJH method.

2.2.2. Transmission electron microscopy (TEM) and energy dispersive $X$ Ray (EDX) analysis

TEM imaging and EDX analysis of the fresh (i.e. reduced) and spent catalysts (after $5 \mathrm{~h}$ reaction at $750{ }^{\circ} \mathrm{C}, \mathrm{CO}_{2} / \mathrm{G}=4$, residence time $=$ $3.75 \mathrm{mg} . \mathrm{min} / \mathrm{Nml}$ ) were performed via a FEI, Tecnai G2 F30 microscope using an electron beam voltage of $300 \mathrm{kV}$. Before TEM-EDX analysis, each sample was dispersed in ethanol and sonicated for $5 \mathrm{~min}$. Then, the sample suspension was transferred on a copper TEM grid by using a micropipette. The excess solution was removed and the copper grid was dried in the fume hood at room temperature overnight. While bright field imaging mode was used for the high resolution TEM (HRTEM) measurements, high angle annular dark field scanning transmission electron microscopy (HAADF-STEM) was utilized for the EDX analysis. Average particle size values were determined using the ImageJ digital image processing software.

\subsubsection{Ex-situ Raman spectroscopic analysis}

Ex-situ Raman spectroscopic experiments were performed on fresh (i.e. reduced) and spent catalysts (after $5 \mathrm{~h}$ reaction at $750{ }^{\circ} \mathrm{C}, \mathrm{CO}_{2} /$ $\mathrm{G}=4$, residence time $=3.75 \mathrm{mg} \cdot \mathrm{min} / \mathrm{Nml}$ ) using a Renishaw inViaReflex confocal Raman microscope/spectrometer by utilizing a $532 \mathrm{~nm}$ laser with an adjustable power where the maximum output laser power at the end of the fiber was $50 \mathrm{~mW}$.

\subsection{4. in-situ FTIR spectroscopic analysis}

in-situ FTIR measurements were carried out in a custom-designed batch-type spectroscopic reactor coupled to an FTIR spectrometer (Bruker Tensor 27) in transmission mode. FTIR spectra were recorded using a Hg-Cd-Te (MCT) detector, where each spectrum was acquired by averaging 32 scans with a spectral resolution of $4 \mathrm{~cm}^{-1}$. Finelyground powder catalyst samples of $\sim 20 \mathrm{mg}$ were pressed onto a lithographically etched W-grid sample holder (i.e. in the absence of $\mathrm{KBr}$ support/diluent material) materials. All of the FTIR spectra were acquired at $50{ }^{\circ} \mathrm{C}$. Other details regarding experimental setup can be 
found elsewhere [37]. in-situ CO adsorption experiments were carried out using FTIR technique by exposing the fresh (i.e. reduced) or spent (obtained after either $5 \mathrm{~h}$ or $72 \mathrm{~h}$ time on stream experiments carried out at $750^{\circ} \mathrm{C}, \mathrm{CO}_{2} / \mathrm{G}=4$ and residence time $=3.75 \mathrm{mg} \cdot \mathrm{min} / \mathrm{Nml}$ ) catalyst surfaces to 10.0 Torr of $\mathrm{CO}(\mathrm{g})$ for $10 \mathrm{~min}$ at $50^{\circ} \mathrm{C}$. Next, spectroscopic chamber was evacuated to $\sim 10^{-2}$ Torr at $50^{\circ} \mathrm{C}$, where FTIR spectra were acquired. Prior to each analysis, background spectrum was collected for each sample after reactor was evacuated to $\sim 10^{-2}$ Torr at $50{ }^{\circ} \mathrm{C}$. Otherwise mentioned, prior to in-situ FTIR analysis, no pretreatment protocols were applied to the fresh and $5 \mathrm{~h}$ spent catalysts.

On the other hand, since the surfaces of the $72 \mathrm{~h}$-spent catalysts were significantly covered with carbonaceous species due to coke deposition during GDR reaction, $72 \mathrm{~h}$-spent catalysts were treated with 10.0 Torr of $\mathrm{H}_{2}$ (purity $>99.999 \%$, Linde $\mathrm{GmbH}$ ) for $10 \mathrm{~min}$ at $300{ }^{\circ} \mathrm{C}$ prior to CO adsorption experiments via in-situ FTIR, in an attempt to remove some of the coke deposition and unravel $\mathrm{Rh}$ nanoparticles to make them available them for $\mathrm{CO}$ adsorption. The background spectrum for $72 \mathrm{~h}$-spent catalyst was collected after pre-treatment as mentioned above.

Nature and relative abundance of the carbonaceous species (which were generated during the GDR process) on the spent catalyst surfaces were also investigated using in-situ FTIR spectroscopy. For this purpose, FTIR spectra of the spent catalysts (without further treatment) were used as the background spectra and the sample in-situ FTIR spectra of the spent catalysts were obtained after exposing them to 10.0 Torr of $\mathrm{H}_{2}$ for $10 \mathrm{~min}$ at $300^{\circ} \mathrm{C}$, followed by evacuation and cooling to $25^{\circ} \mathrm{C}$.

\subsection{Catalytic performance experiments}

The catalytic performance tests were carried out in a down flow, quartz tubular packed bed reactor positioned in a three-zone furnace (Protherm PZF 12/50/500) as presented in Fig. 1. The quartz tube was $8 \times 10^{-1} \mathrm{~m}$ long with an internal diameter (ID) of $2 \times 10^{-2} \mathrm{~m}$ and narrowed down to an ID of $1 \times 10^{-2} \mathrm{~m}$ along the central $1.5 \times 10^{-1} \mathrm{~m}$ length of the tube. The vertically positioned furnace had a heated length of $5 \times 10^{-1} \mathrm{~m}$ which involved three equidistant zones with dedicated PID controllers capable of regulating the pertinent zone temperature to $\pm 1.0^{\circ} \mathrm{C}$ via K-type thermocouples positioned at the midpoints of the zones. The catalyst bed, composed of a physical mixture of $20 \mathrm{mg}$ of catalyst (RhZr or RhCe) and $700 \mathrm{mg}$ of diluent ( $\alpha$ $\mathrm{Al}_{2} \mathrm{O}_{3}$, Alfa-Aesar), both at the particle size range of $2.5-3.5 \times 10^{-4} \mathrm{~m}$, was positioned at the middle of the second zone via a quartz wool plug that was supported by a specially designed inset existing within the narrower section of the quartz tube (with ID of $1 \times 10^{-2} \mathrm{~m}$ ) to prevent any physical movement of the bed. The resulting configuration gave a packed bed height of $\sim 1 \times 10^{-2} \mathrm{~m}$ to obtain bed height-to-particle diameter and tube diameter-to-particle diameter ratios of $\sim 35$, which were acceptable for ignoring diffusive transport terms and assuming plug flow behavior, respectively [38,39]. In all conditions pressure drop remained negligible $(<1 \%)$ as simulated in CHEMCAD 7.1.4 chemical process simulation software. Absence of pressure drop was also confirmed experimentally by the steady, pulse-free flow of reactor effluent that was periodically monitored via directing it to a soap-bubble meter.

Liquid glycerol (Sigma-Aldrich, purity: 99.5\%) was precisely metered by a Shimadzu LC-20AD HPLC pump and transported via a 1/16inch outer diameter (OD) stainless steel tubing to the inlet of the quartz tube, where it contacted with $\mathrm{CO}_{2}$ and $\mathrm{N}_{2}$, both supplied by Linde $\mathrm{GmbH}$ with purities above $99.995 \%$ and metered by Brooks $5850 \mathrm{E}$ Series Mass Flow Controllers (Fig. 1). The gas-liquid mixture was then introduced into the quartz tube through a 1/16-inch OD stainless steel tubing acting as an injector. The tubing extended until $1 \times 10^{-1} \mathrm{~m}$ into the first zone of the furnace, where the temperature was kept above $400{ }^{\circ} \mathrm{C}$. This scheme enabled complete evaporation and continuous feeding of glycerol and ensured that the desired $\mathrm{CO}_{2} / \mathrm{G}$ feed ratio was obtained. After evaporation and mixing within the injector, the reactive mixture reached the catalyst bed located at the middle of the second zone of the furnace, where the temperature was set to the specified reaction temperature. The third zone of the furnace was kept above $350{ }^{\circ} \mathrm{C}$ to prevent any condensation within the downstream of the catalyst bed. After having left the quartz tube, the effluent stream was passed through two consecutive cold traps to knock out any condensable components such as water, unreacted glycerol or any other possible liquid-phase products of glycerol decomposition (Fig. 1). The remaining gaseous mixture was transferred to two on-line gas chromatographs (GCs) for qualitative and quantitative analysis. The first GC, Shimadzu GC-2014, was equipped with a thermal conductivity detector (TCD, detector temperature and current of $150{ }^{\circ} \mathrm{C}$ and $50 \mu \mathrm{A}$, respectively) and a 60-80 mesh size Molecular Sieve 5 A packed column operated under $25 \mathrm{Nml} / \mathrm{min} \mathrm{Ar}$ (purity > 99.99\%, Linde GmbH) carrier gas flow at $50{ }^{\circ} \mathrm{C}$ to detect $\mathrm{H}_{2}, \mathrm{~N}_{2}, \mathrm{CH}_{4}$ and $\mathrm{CO}$. The second GC, Agilent $6850 \mathrm{~N}$, involved an 80-100 mesh size Porapak Q packed column and $20 \mathrm{Nml} / \mathrm{min} \mathrm{He}$ (purity $>99.99 \%$, Linde $\mathrm{GmbH}$ ) carrier gas flow at $40{ }^{\circ} \mathrm{C}$ to quantify the amounts of $\mathrm{N}_{2}, \mathrm{CO}_{2}, \mathrm{CH}_{4}, \mathrm{C}_{2} \mathrm{H}_{4}$ and $\mathrm{C}_{2} \mathrm{H}_{6}$ in the product mixture via TCD (detector temperature and current of $150{ }^{\circ} \mathrm{C}$ and $120 \mu \mathrm{A}$, respectively). Settings of the GC units ensured reproducible detection of the specified molecules at ppm levels. Sample injection to both GC units was realized by six-way sampling valves, each of which involved sample loops of $1 \mathrm{~mL}$ volume.

Catalytic activity measurements were carried out by varying reaction temperature (T), $\mathrm{CO}_{2} / \mathrm{G}$ and residence time within $600-750{ }^{\circ} \mathrm{C}, 0-4$ and $0.5-5.5 \mathrm{mg} \cdot \mathrm{min} / \mathrm{Nml}$, respectively. Residence time was defined as the ratio of mass of catalyst $\left(\mathrm{mg}_{\text {catalyst }}\right)$ to the inlet volumetric flow rate of the reactive mixture $(\mathrm{Nml} / \mathrm{min})$ and was varied by regulating the catalyst quantity. Parametric study was carried out by changing a single parameter value in its pertinent range, while keeping other parameters constant at their default values (i.e. $750{ }^{\circ} \mathrm{C}, 1$ and $0.5 \mathrm{mg} \cdot \mathrm{min} / \mathrm{Nml}$ ). Catalyst samples tested in characterization studies as well as in $72 \mathrm{~h}$ time-on-stream tests, however, were obtained from experiments carried out at residence times above $0.5 \mathrm{mg}$. $\mathrm{min} / \mathrm{Nml}$ for magnifying the impacts of phenomena such as sintering, deposition of carbonaceous species, etc. on the catalyst surface via its elongated interaction with the reactive mixture. In all experiments, inlet flow rate of glycerol vapor was fixed at $4 \mathrm{Nml} / \mathrm{min}$. $\mathrm{CO}_{2}$ flow rate was determined according to the value of $\mathrm{CO}_{2} / \mathrm{G}$ ratio and $\mathrm{N}_{2}$ was used as an inert balance gas to fix the total inlet flow rate at $40 \mathrm{Nml} / \mathrm{min}$. Except the $72 \mathrm{~h}$ time-onstream runs, duration of all experiments was set as $5 \mathrm{~h}$. Product sampling and analysis were first carried out for $30 \mathrm{~min}$ after the initiation of the experiments, and continued periodically at every $45 \mathrm{~min}$. The results reported in this study were based on the arithmetic average of the outcomes of the product analysis done between $2^{\text {nd }}$ and $5^{\text {th }} \mathrm{h}$ of the experiments where the reaction was found to exhibit a steady state pattern.

Catalytic performance was evaluated in terms of $\mathrm{CO}_{2}$ conversion $\left(X_{\mathrm{CO}_{2}}\right)$, glycerol conversion to gaseous products $\left(X_{G}\right)$ and product yields $\left(Y_{i}\right)$ :

$X_{\mathrm{CO}_{2}}(\%)=\frac{F_{\mathrm{CO}_{2}, \text { in }}-F_{\mathrm{CO}_{2}}}{F_{\mathrm{CO}_{2}, \text { in }}} \times 100$

$X_{G}(\%)=\frac{2 F_{H_{2}}+4 F_{C_{4}}+4 F_{C_{2} H_{4}}+6 F_{C_{2} H_{6}}}{8 F_{G, i n}} \times 100$

$Y_{i}=\frac{\text { moles of species } i \text { in gaseous products }}{\text { moles of glycerol fed }}$

In Eqs. (9)-(11) $F_{i}$ and $F_{i, \text { in }}$ refer to the molar flow rate of species $i$ in the product and feed streams (both in $\mathrm{mol} / \mathrm{min}$ ), respectively. Since product analysis was done on the basis of gaseous species, it was not possible to calculate glycerol conversion from the molar flow rate of glycerol in the product stream. In this case, as commonly done in the literature [17-24] an atomic balance over hydrogen was conducted to calculate the amount of converted glycerol. Molar flow rates of all gaseous products that contain $\mathrm{H}$ atoms were used in the calculation, as 
shown in Eq. 10. It should be noted, however, that condensable species such as steam and oxygenated $\mathrm{C}_{2+}$ hydrocarbons that involve $\mathrm{H}$-atoms and potentially exist in the product mixture were not included in the calculation. Possible existence of hydrocarbons other than $\mathrm{CH}_{4}, \mathrm{C}_{2} \mathrm{H}_{4}$ and $\mathrm{C}_{2} \mathrm{H}_{6}$ within the reaction mixture were controlled by thermodynamic analysis calculations explained in Section 3.2.1. The outcomes did not predict presence of any oxygenated $\mathrm{C}_{2}+$ species within the map of parametric study. Moreover, owing to the very high activity of Rhbased catalysts for steam reforming of hydrocarbons [40], complete removal of the in-situ generated steam (via RWGS, Reaction 2) by its interaction with $\mathrm{CH}_{4}$ (via Reaction 4) and with $\mathrm{C}_{2} \mathrm{H}_{4}$ and $\mathrm{C}_{2} \mathrm{H}_{6}$ was very likely to occur as also shown in Section 3.2.2. These statements could then serve for the validation of the assumptions made in the formulation of Eq. (10) which would eventually give the conversion of glycerol into gaseous products, namely $\mathrm{H}_{2}, \mathrm{CH}_{4}, \mathrm{C}_{2} \mathrm{H}_{4}$ and $\mathrm{C}_{2} \mathrm{H}_{6}$.

Reliability of the catalyst testing and product analysis systems were found to be reproducible in all cases within $<1 \%$ of the measurements and was verified by the outcomes $\left(X_{\mathrm{CO}_{2}}, X_{G}\right.$ and $\left.Y_{i}\right)$. In addition to the catalytic experiments, blank tests involving only quartz wool and diluent $\left(\alpha-\mathrm{Al}_{2} \mathrm{O}_{3}\right)$ were also conducted within the entire parameter range ( $\mathrm{T}=600-750^{\circ} \mathrm{C}, \mathrm{CO}_{2} / \mathrm{G}=0-4$ ) in order to detect any activity associated with $\alpha-\mathrm{Al}_{2} \mathrm{O}_{3}$ and to quantify the effect of temperature and $\mathrm{CO}_{2} /$ $\mathrm{G}$ ratio on homogeneous decomposition of glycerol. As expected, outcomes of the blank tests did not change with the existence of $\alpha-\mathrm{Al}_{2} \mathrm{O}_{3}$ due to its low surface area $\left(<5 \mathrm{~m}^{2} / \mathrm{g}\right)$ and well-known inert nature. As additional blank experiments, pure support materials (i.e. $\mathrm{ZrO}_{2}$ and $\mathrm{CeO}_{2}$ ) were also tested at $750{ }^{\circ} \mathrm{C}$ and $\mathrm{CO}_{2} / \mathrm{G}=4$ (i.e. conditions leading to the highest $\mathrm{CO}_{2}$ conversions) to provide insight into their possible contributions to the breakdown of $\mathrm{CO}_{2}$.

\section{Results and discussion}

\subsection{Structural and functional characterization studies}

\subsubsection{Surface area and porosity measurements}

Results of specific surface area (SSA), average pore volume and average pore size measurements obtained via $\mathrm{N}_{2}$ physisorption on the support materials calcined at $800^{\circ} \mathrm{C}$ for $4 \mathrm{~h}$ are presented in Table 1 . It is observed that both $\mathrm{ZrO}_{2}$ and $\mathrm{CeO}_{2}$ had limited SSA, as expected from the high calcination temperatures used in the synthesis (i.e. $800^{\circ} \mathrm{C}$ ). These findings are in alignment with those reported in the literature. For instance, Zhao et al. [41] stated a strong correlation between $\mathrm{ZrO}_{2}$ SSA and calcination temperature, and reported a BET specific surface area of $15 \mathrm{~m}^{2} / \mathrm{g}$ for $\mathrm{ZrO}_{2}$ calcined at $800^{\circ} \mathrm{C}$. Moreover, da Silva et al. [27] used the same method for preparing $\mathrm{CeO}_{2}$ that is used in the current study and reported a SSA of $14 \mathrm{~m}^{2} / \mathrm{g}$. A $60 \%$ greater SSA observed for $\mathrm{ZrO}_{2}$ as compared to that of $\mathrm{CeO}_{2}$ is in line with the better dispersion of $\mathrm{Rh}$ on the former support material as will be discussed in the forthcoming sections.

\subsubsection{TEM and EDX measurements}

Figs. 2 and 3 present the TEM and EDX analysis of the fresh (i.e. reduced) and spent forms of the RhZr (Fig. 2) and RhCe (Fig. 3) catalysts obtained after their $5 \mathrm{~h}$ use in GDR reaction $\left(750^{\circ} \mathrm{C}, \mathrm{CO}_{2} / \mathrm{G}=4\right.$, residence time $=3.75 \mathrm{mg} \cdot \mathrm{min} / \mathrm{Nml}$ ). Fig. $2 \mathrm{a}$ and $\mathrm{b}$ show the morphology of the fresh RhZr catalyst, where the distinct shape of the Rh

Table 1

Results of $\mathrm{N}_{2}$ physisorption analysis on $\mathrm{ZrO}_{2}$ and $\mathrm{CeO}_{2}$ catalyst support materials calcined at $800{ }^{\circ} \mathrm{C}$ for $4 \mathrm{~h}$.

\begin{tabular}{llll}
\hline Support & $\begin{array}{l}\text { Specific surface area } \\
\left(\mathrm{m}^{2} / \mathrm{g}\right)\end{array}$ & $\begin{array}{l}\text { Pore volume } \\
(\mathrm{ml} / \mathrm{g})\end{array}$ & $\begin{array}{l}\text { Average pore size } \\
(\AA)\end{array}$ \\
\hline $\mathrm{ZrO}_{2}$ & 16.3 & $2.59 \times 10^{-2}$ & 16.2 \\
$\mathrm{CeO}_{2}$ & 10.2 & $1.76 \times 10^{-2}$ & 15.0 \\
\hline
\end{tabular}

particles dispersed on $\mathrm{ZrO}_{2}$ support could be clearly observed, particularly in the HR-TEM image given in Fig. 2b. Presence of Rh and $\mathrm{Zr}$ in the catalyst composition and lack of any significant impurities were also verified by STEM-EDX analysis as shown in Fig. 2c and d. Analogous measurements performed on the $5 \mathrm{~h}$-spent RhZr catalyst is also presented in Fig. 2e-h. Using the TEM data, average particle size of Rh nanoparticles on fresh and $5 \mathrm{~h}$-spent RhZr catalysts were estimated to be $2.1 \mathrm{~nm}( \pm 0.4 \mathrm{~nm})$ and $4.1 \mathrm{~nm}( \pm 1.1 \mathrm{~nm})$, respectively (via ImageJ software). This observation suggests that Rh nanoparticles grew bigger and sintered during the GDR reaction conditions.

Fig. 3a-h illustrate TEM-STEM-EDX analysis of the fresh and $5 \mathrm{~h}$ spent RhCe catalysts which were exposed to the identical reaction conditions to that of the RhZr catalyst. HR-TEM images given in Fig. 3b and $f$ clearly reveal the truncated cubo-octahedral geometry of the Rh particles revealing atomically well-defined planar facets. Ordered structure of the $\mathrm{CeO}_{2}$ domains is also visible in Fig. $3 \mathrm{~b}$ and f, presenting a readily distinguishable morphology as compared to that of the $\mathrm{Rh}$ nanoparticles. Existence of $\mathrm{Rh}$ and $\mathrm{Ce}$ in the catalyst structure was demonstrated by STEM-EDX analysis as shown in Fig. 3c and g. Average particle sizes of the $\mathrm{Rh}$ nanoparticles on the $\mathrm{CeO}_{2}$ domains before and after GDR reaction were estimated using the TEM data and ImageJ software for the fresh and $5 \mathrm{~h}$-spent RhCe catalysts. It was found that fresh and $5 \mathrm{~h}$-spent RhCe catalysts had comparable average Rh particles sizes of $3.5 \mathrm{~nm}( \pm 0.6 \mathrm{~nm})$ and $3.4 \mathrm{~nm}( \pm 1.3 \mathrm{~nm})$, respectively. It is apparent that unlike the $\mathrm{Rh}$ particles on the $\mathrm{ZrO}_{2}$ support, $\mathrm{Rh}$ particles on $\mathrm{CeO}_{2}$ resisted sintering under the identical GDR reaction conditions. In other words, it is likely that surface diffusion and mobility of the Rh nanoparticles were significantly suppressed by the strong interaction between $\mathrm{Rh}$ and $\mathrm{CeO}_{2}$ domains. These observations are in very good accordance with the current in-situ FTIR spectroscopic results (Section 3.1.3) providing additional evidence for the existence of a strong metal support interaction on the RhCe catalyst and sintering of the Rh nanoparticles on $\mathrm{ZrO}_{2}$ after the GDR reaction as will be further discussed in upcoming sections.

\subsection{3. in-situ FTIR spectroscopic experiments}

Fig. 4 shows the functional characterization of the fresh (i.e. reduced), $5 \mathrm{~h}$ and $72 \mathrm{~h}$-spent RhZr and RhCe catalysts (after reaction at $750{ }^{\circ} \mathrm{C}, \quad \mathrm{CO}_{2} / \mathrm{G}=4$, residence time $=3.75 \mathrm{mg} \cdot \mathrm{min} / \mathrm{Nml}$ ) via in-situ FTIR spectroscopy. In these experiments, $\mathrm{CO}(\mathrm{g})$ was used as a probe molecule in order to shed light on the electronic and morphological properties of the $\mathrm{Rh}$ actives sites on the catalyst surfaces as well as their interaction with the support materials (i.e. $\mathrm{ZrO} 2$ or CeO2). in-situ 2 FTIR spectrum in Fig. 4a corresponding to the fresh RhZr catalyst reveals several strong vibrational features associated with different $\mathrm{CO}(a d s)$ species. Vibrational features at 2090 and $2011 \mathrm{~cm}^{-1}$ can be assigned to the symmetric and antisymmetric stretchings of gem-dicarbonyl species on $\mathrm{Rh}^{+}$sites (i.e. $\mathrm{Rh}^{+}(\mathrm{CO})_{2}$ ) [42-44]. Intense IR band at $2048 \mathrm{~cm}^{-1}$ is associated with linear (atop) $\mathrm{CO}(a d s)$ on metallic Rh sites. On the other hand, vibrational features appearing at lower frequencies correspond to $\mathrm{CO}$ adsorbed on high-coordination metallic Rh sites. Namely, $1912 \mathrm{~cm}^{-1}$ signal can be attributed to CO adsorbed on two-fold (bridging) metallic Rh sites; while the IR feature at $1835 \mathrm{~cm}^{-1}$ can be assigned to $\mathrm{CO}$ adsorption on three-fold (hollow) metallic Rh sites [45-47]. It has been demonstrated in the literature that CO adsorbed on $\mathrm{Rh}^{3+}$ sites in a linear (atop) fashion led to a weak vibrational signal located at $2137 \mathrm{~cm}^{-1}$. As $\mathrm{Rh}^{3+}$ sites could readily be reduced to $\mathrm{Rh}^{+}$in the presence of $\mathrm{CO}(\mathrm{g})$, detection of this feature was reported to be rather elusive [48]. Although a very weak signal is probably present in Fig. $4 \mathrm{a}$ at $2137 \mathrm{~cm}^{-1}$, due to the extremely low intensity of this feature, it is not possible to conclusively suggest the presence of $\mathrm{Rh}^{3+}-\mathrm{CO}$ species on the fresh RhZr catalyst surface.

in-situ FTIR spectra given in Fig. 4a provide valuable insights regarding the electronic nature of the $\mathrm{Rh}$ sites on $\mathrm{ZrO}_{2}$ support surface. Co-existence of $\mathrm{Rh}$ and $\mathrm{Rh}^{+}$features indicates that both metallic and oxidic Rh sites may be simultaneously present on the RhZr fresh 

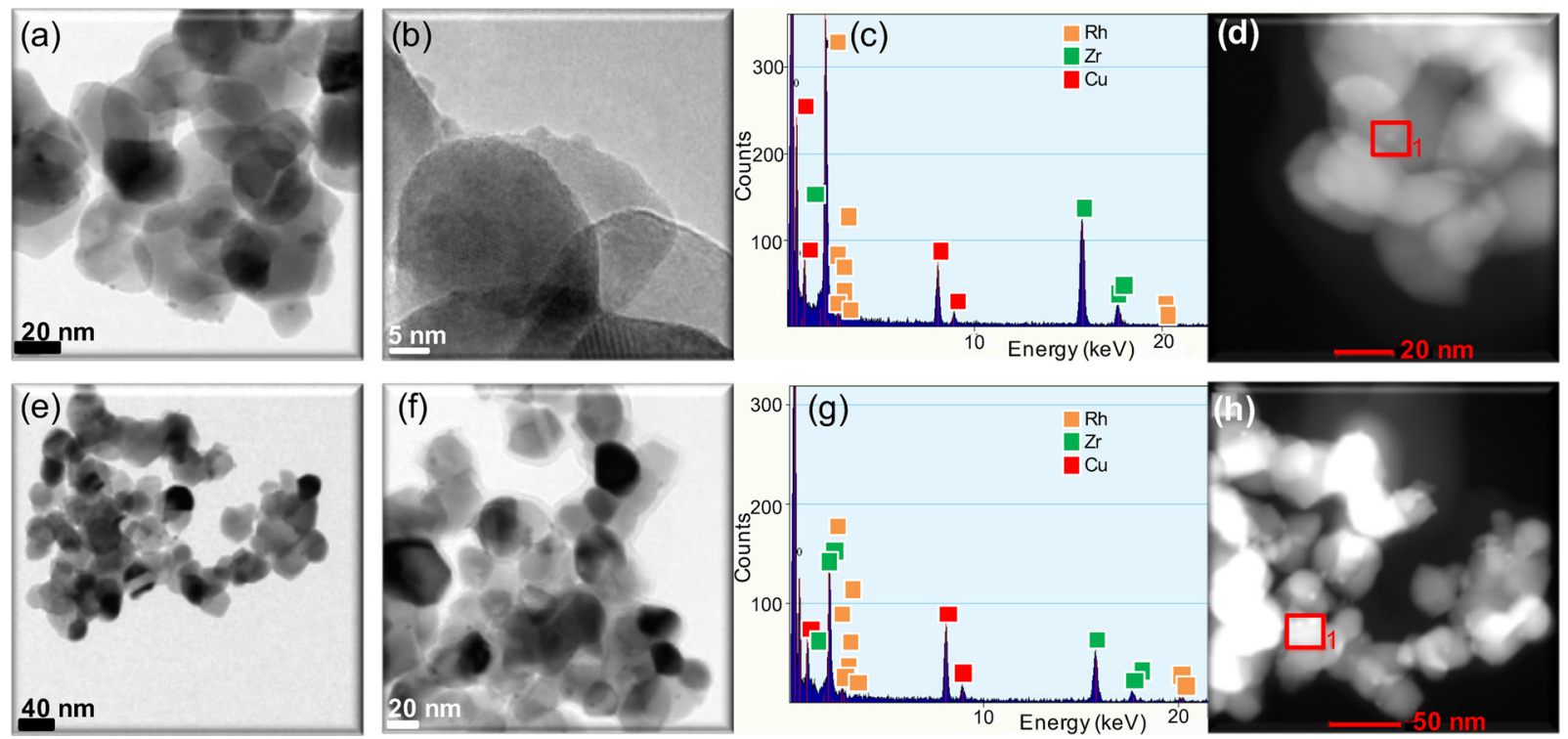




this article).

catalyst surface. This can be explained by the exchange of oxygen between $\mathrm{ZrO}_{2}$ lattice (generating oxygen vacancies) and the $\mathrm{Rh}$ metal (creating oxidic $\mathrm{Rh}^{+}$species). $\mathrm{Rh}^{+}$species could be also generated with the assistance of gas phase oxygen during the calcination step of the catalyst synthesis protocol.

Currently mentioned observations/explanations about the oxidation state of the precious metal sites on the metal oxide support after calcination is nothing but classical and have been reported in the literature frequently. As we clearly mentioned in the current text, rhodium can be present on the $\mathrm{ZrO}_{2}$ surface in the forms of $\mathrm{Rh}^{0}, \mathrm{Rh}^{+}$, or $\mathrm{Rh}^{3+} . \mathrm{Rh}^{3+}$ can exist on the surface due to the preservation of the original oxidation state of the Rh(III) nitrate precursor with or (more likely) without nitrate. After calcination, replacement/decomposition of the nitrate precursor to $\mathrm{NO}+\mathrm{O}_{2}$ and/or $\mathrm{NO}_{2}+1 / 2 \mathrm{O}_{2}$ may lead to the replacement of nitrates with oxide anions. Moreover, detection of $\mathrm{Rh}^{3+}$ becomes difficult during the in-situ FTIR experiments as, in the presence of $\mathrm{CO}$, oxide ions coordinated to $\mathrm{Rh}^{3+}$ can be consumed in $\mathrm{CO}$ oxidation $\left(\mathrm{CO}+\mathrm{O}_{2} \rightarrow \mathrm{CO}_{2}\right.$ ) leading to reduction of $\mathrm{Rh}^{3+}$ to $\mathrm{Rh}^{+}$. Finally, formation of metallic sites after calcination occurs either due to the total thermal decomposition of the Rh(III) nitrate (i.e. electron transfer from nitrate anion to $\mathrm{Rh}^{3+}$ and/or $\mathrm{Rh}^{+}$cations during nitrate decomposition to $\mathrm{NO}+\mathrm{O}_{2}$ and/or $\mathrm{NO}_{2}+1 / 2 \mathrm{O}_{2}$ ) or due to the reduction of $\mathrm{Rh}^{3+}$ and $\mathrm{Rh}^{+}$with $\mathrm{CO}$ during the in-situ FTIR experiments. As also mentioned in the text, an alternative way of $\mathrm{Rh}^{+}$generation is the oxygen vacancy formation on $\mathrm{ZrO}_{2}$ and oxygen transfer to metallic $\mathrm{Rh}$.

in-situ FTIR data also offer information about the morphology of the $\mathrm{Rh}$ nanoparticles. Presence of an intense IR band at $2046 \mathrm{~cm}^{-1}$ corresponding to the linear (atop) $\mathrm{CO}(a d s)$ on metallic Rh sites; co-existing with weak IR bands for $\mathrm{CO}$ adsorbed on two-fold and three-fold metallic $\mathrm{Rh}$ sites suggests that $\mathrm{Rh}$ particles on $\mathrm{ZrO}_{2}$ do not expose extremely


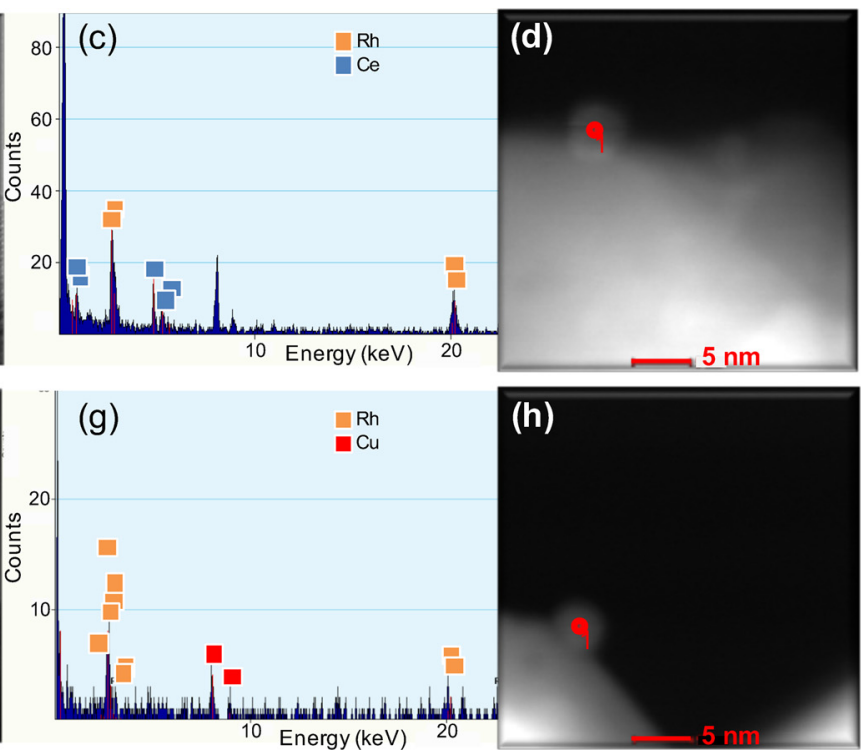

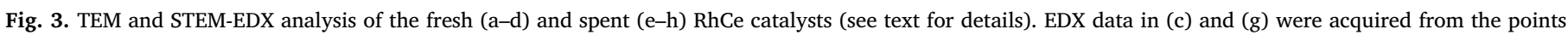

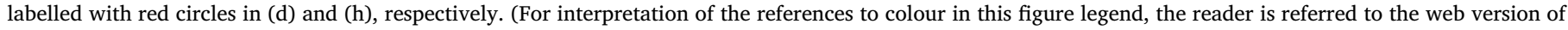
this article). 


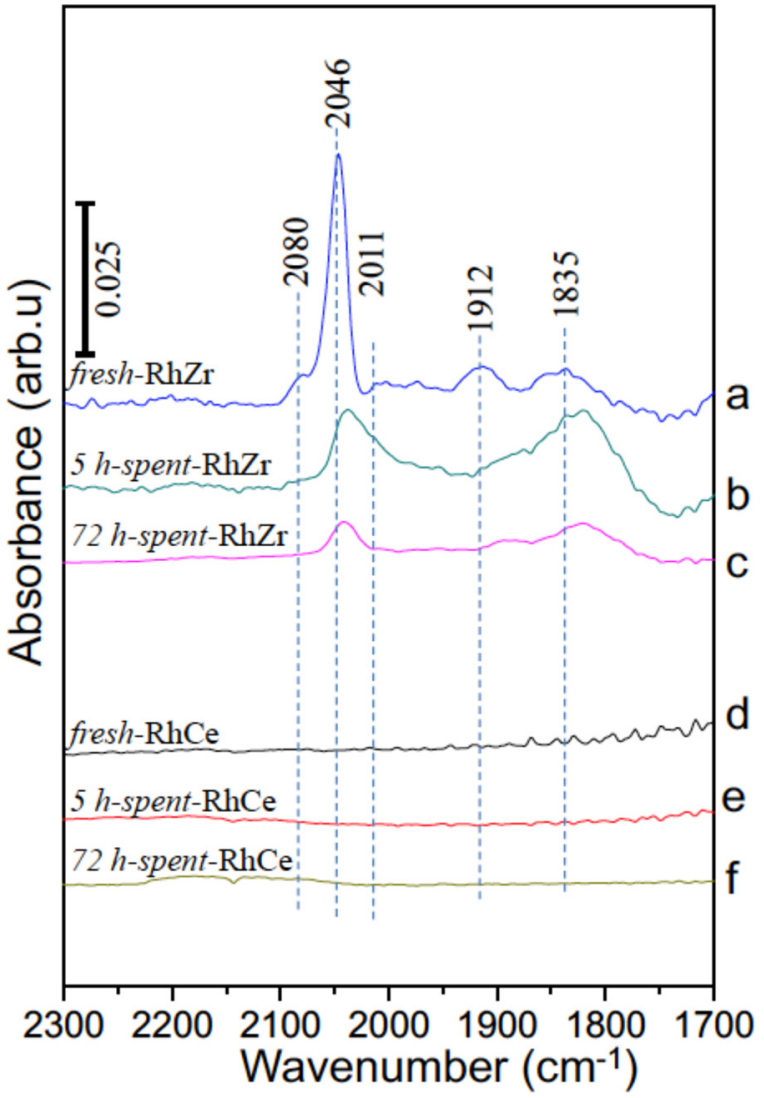

Fig. 4. In-situ FTIR spectra corresponding to 10 Torr $\mathrm{CO}(\mathrm{g})$ adsorption at $25{ }^{\circ} \mathrm{C}$ for 10 min on (a) fresh RhZr, (b) 5 h-spent RhZr, (c) 72 h-spent RhZr, (d) fresh RhCe, (e) 5 h-spent RhCe, and (f) $72 \mathrm{~h}$-spent RhCe. Before the acquisition of the $72 \mathrm{~h}$-spent catalyst spectra presented in (c) and (f), catalysts were treated with 10 Torr $\mathrm{H}_{2}(\mathrm{~g})$ at $300{ }^{\circ} \mathrm{C}$ for $10 \mathrm{~min}$ followed by cooling to $25^{\circ} \mathrm{C}$ and evacuation.

large (i.e. extended) facets and possess a high concentration of point defects or extended defects (e.g. corners, kinks, step edges etc.) which favor linear $\mathrm{CO}$ adsorption. These findings are consistent with the presence of small $\mathrm{Rh}$ particles on the fresh RhZr catalyst with a relatively fine dispersion. This is in line with the TEM results given in Fig. 2 revealing an average $\mathrm{Rh}$ particle size of $2.1 \mathrm{~nm}$.

Upon aging of the RhZr catalyst for $5 \mathrm{~h}$ under GDR reaction conditions, striking changes appeared in the corresponding in-situ FTIR spectrum as shown in Fig. 4b. It is apparent that the Rh-CO feature at $2046 \mathrm{~cm}^{-1}$ drastically attenuated, while the IR bands associated with $\mathrm{CO}$ adsorbed on high-coordination metallic Rh sites grew in intensity. One possible cause for the attenuated Rh-CO signal for the $5 \mathrm{~h}$-spent catalyst could be the deposition of carbonaceous species on the Rh sites and/or burial of the Rh sites by the $\mathrm{ZrO}_{2}$ support material. This argument will be further justified by the current ex-situ Raman analysis of the $5 \mathrm{~h}$-spent RhZr catalyst (Fig. 5). In addition, attenuation of the linear-bound $\mathrm{CO}$ species at the expense of the growing two-fold and three-fold adsorbed CO signals may also point to the fact that upon catalyst aging and deactivation, average particle size of Rh increased and $\mathrm{Rh}$ nanoparticles started to expose wider extended facets revealing a greater number of two-fold and three-fold adsorption sites. Such an argument is in very good harmony with the average Rh particle size value of the $5 \mathrm{~h}$-spent RhZr catalyst obtained from TEM analysis given in Fig. $2(4.1 \mathrm{~nm})$ which was significantly greater than that of the fresh RhZr catalyst $(2.1 \mathrm{~nm})$.

Interestingly, $\mathrm{CO}(\mathrm{g})$ adsorption on $72 \mathrm{~h}$-spent $\mathrm{RhZr}$ revealed no vibrational features (data not shown) due to relatively severe aging, deactivation and coke deposition. In order to unravel the underlying $\mathrm{Rh}$ sites on the coke-covered $72 \mathrm{~h}$-spent RhZr catalyst, we treated the

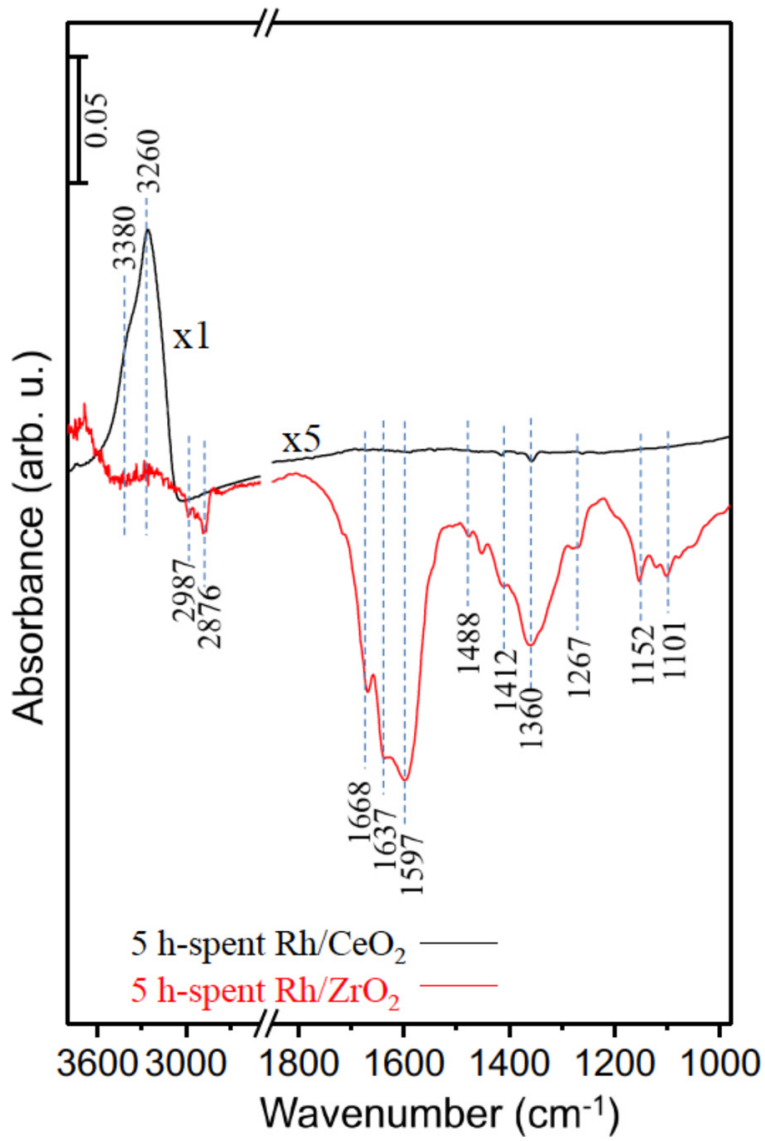

Fig. 5. In-situ FTIR spectra corresponding to $5 \mathrm{~h}$-spent RhZr, and $5 \mathrm{~h}$-spent RhCe catalysts obtained after treatment with 10 Torr $\mathrm{H}_{2}(\mathrm{~g})$ at $300{ }^{\circ} \mathrm{C}$ for $10 \mathrm{~min}$ followed by cooling to $25^{\circ} \mathrm{C}$ and evacuation. Note that for this set of spectra, background spectra belong to the spent catalysts before the hydrogen treatment.

catalyst with $\mathrm{H}_{2}(\mathrm{~g})$ at $300{ }^{\circ} \mathrm{C}$ in the in-situ FTIR spectroscopic cell; in an attempt to gasify the coke and create available Rh sites for $\mathrm{CO}$ adsorption. These results are shown in Fig. 4c. General characteristics of the in-situ FTIR spectrum corresponding to the $72 \mathrm{~h}$-spent RhZr catalyst were comparable to that of the $5 \mathrm{~h}$-spent RhZr catalyst although IR intensities were typically lower in the former case. This is possibly due the fact that even after $\mathrm{H}_{2}$ treatment and removal of some of the coke deposit, there exist still considerable amount of carbonaceous species on the $72 \mathrm{~h}$-spent RhZr catalyst.

In the current results, decreasing intensities of the $\mathrm{CO}(a d s)$ IR signals for the $72 \mathrm{~h}$-spent RhZr catalyst may also indicate the loss of exposed Rh sites due to $\mathrm{Rh}$ particle size growth (i.e. decreasing dispersion) and/or migrating of $\mathrm{Rh}$ into the $\mathrm{ZrO}_{2}$ matrix by strong metal support interaction. Evolution of the in-situ FTIR data for $\mathrm{CO} / \mathrm{RhZrO}_{2}$ upon exposure to reaction conditions may correspond to $\mathrm{Rh}$ diffusion into the $\mathrm{ZrO}_{2}$ matrix because, increasing durations of reaction time leads to a monotonic and significant decrease in the FTIR peak intensities consistent with the loss of exposed Rh sites. On the other hand, particular loss of the intense $2046 \mathrm{~cm}^{-1}$ and the less prominent $2080 \mathrm{~cm}^{-1}$ bands of the fresh catalyst originating from linearly bound (on-top/atop) CO species adsorbed on kinks/edges/corners of the small clusters upon aging under reaction conditions suggest that these defect sites are replaced with non-defective terraces on larger particles where $\mathrm{CO}$ can bind with higher coordination (bridging \& three-fold) yielding much lower vibrational frequencies in FTIR.

Fig. 4d-f show the analogous in-situ FTIR spectra obtained after CO (g) adsorption on fresh, $5 \mathrm{~h}$-spent and $72 \mathrm{~h}$-spent RhCe catalysts. As described earlier, for the $72 \mathrm{~h}$-spent catalyst, a coke removal procedure 
was also employed with $\mathrm{H}_{2}(\mathrm{~g})$ at $300^{\circ} \mathrm{C}$. Interestingly, none of these RhCe catalysts revealed any significant $\mathrm{CO}(a d s)$ vibrational signals. It is interesting that even though the fresh RhCe catalyst did not possess any coke deposit, it still did not reveal any signs of CO adsorption. This indicates that there were no exposed Rh sites on the surface of the fresh $\mathrm{RhCe}$ catalyst and the Rh sites were covered with the ceria support material. It was previously highlighted that reducible oxides (i.e. $\mathrm{CeO}_{2}$ ) can go through the formation of strong chemical bonds to precious metals and embedding metal particles inside the lattice which can even further enhance reaction rate by up to 100 fold $[49,50]$. Moreover, a similar interaction between platinum and ceria was shown to lead up to 20 -fold enhancement in the catalytic activity for the water gas shift reaction. This increase in activity was further confirmed by the density functional theory calculations which revealed that the electronic interaction between metal particles smaller than ca. $7 \mathrm{~nm}$ and ceria support can significantly decrease the activation barrier for water dissociation $[51,52]$. Therefore, although Rh sites seem to be covered with ceria for the fresh and spent RhCe, higher activity of RhCe catalyst could be attributed to strong electronic interaction between small $\mathrm{Rh}$ particles and $\mathrm{CeO}_{2}$ lattice which may possibly lead to formation of Rh$\mathrm{O}$-Ce type of surface species as well as $\mathrm{Rh} / \mathrm{Rh}^{+}$particles on supportmetal interface which are not feasible to probe the properties of Rh sites further with $\mathrm{CO}(\mathrm{g})$ adsorption.

In addition, in the current study, it should be noted that, all catalysts were treated under identical conditions including pressure, time, temperature, mass, etc. and all measurements were repeated at least twice in order to assure reproducibility of the results. Utilized, CO pressures, exposures and durations are within typical/standard values which have been used on similar catalysts in hundreds of former studies in the literature since 1970's. Here it is obvious that differences in the CO adsorption of $\mathrm{Rh} / \mathrm{Ce}$ and $\mathrm{Rh} / \mathrm{Zr}$ are associated with the differences in the intrinsic nature $\mathrm{Rh}$ species, Rh dispersion, particle size and extent of the interaction of $\mathrm{Rh}$ with different support oxides, $\mathrm{CeO}_{2}$ and $\mathrm{ZrO}_{2}$. Moreover, it was pointed out that ceria can adsorb $\mathrm{CO}$ in the form of carbonates, carboxylates and formates [53]. These species have vibrational features below the carbonyl region of interest (i.e. $<1800 \mathrm{~cm}^{-1}$ ) and were also observed in our current experiments (data not shown). Thus here, we merely report the absence of carbonyls on Rh sites of Rh/ Ce but do not mean to entirely exclude CO adsorption on ceria in the form of carbonates, carboxylates and formates.

However, valuable information regarding the aging and coking of the spent catalysts can also be inferred via in-situ FTIR spectroscopy. This can be accomplished by investigating the differences between the vibrational features of the carbonaceous species on the $5 \mathrm{~h}$-spent RhZr and $5 \mathrm{~h}$-spent RhCe catalysts before and after their treatment with 10 Torr $\mathrm{H}_{2}(\mathrm{~g})$ at $300^{\circ} \mathrm{C}$ for $10 \mathrm{~min}$. In these set of experiments, IR spectra of the $5 \mathrm{~h}$-spent catalysts were used as the background spectra and the in-situ FTIR spectra of the $5 \mathrm{~h}$-spent catalysts after hydrogen treatment (in the in-situ spectroscopic cell) was subtracted from these background spectra (Fig. 5). In other words, the difference spectra given in Fig. 5 depict the loss of carbonaceous species on the $5 \mathrm{~h}$-spent catalysts through hydrogen assisted gasification of coke. It is apparent in Fig. 5 that on the $5 \mathrm{~h}$-spent RhCe catalyst, hydrogen treatment resulted in no significant changes in the vibrational frequency region within 1800-1000 $\mathrm{cm}^{-1}$, where coke signatures were expected (note that the corresponding RhCe spectrum in this region is multiplied by 5). On the other hand, hydrogen treatment leads to intense positive features in the spectral range of $3600-3000 \mathrm{~cm}^{-1}$, which can be attributed to the formation of $-\mathrm{O}-\mathrm{H}$. This finding indicates that $\mathrm{H}_{2}$ can be readily activated on the $5 \mathrm{~h}$-spent RhCe surface which is still mostly free of coke, generating atomic hydrogen which can adsorb on accessible surface Lewis basic sites (i.e. $\mathrm{O}^{2-}$ ) of ceria and form surface hydroxyl species [54-56].

In stark contrast, hydrogen treatment of the $5 \mathrm{~h}$-spent RhZr catalyst generated a variety of strong negative IR bands within 1800-1000 $\mathrm{cm}^{-1}$, in addition to another set of weaker negative bands within
$3000-2850 \mathrm{~cm}^{-1}$. Due to the complex and overlapping nature of these negative IR bands, it is difficult to provide an unambiguous assignment for all of the possible species that can be attributed to these peaks. However, the negative IR band at $1412 \mathrm{~cm}^{-1}$ can be attributed to the loss of ionic carbonates, while the negative bands at 1597 and $1360 \mathrm{~cm}^{-1}$ can be associated with the loss of $\nu \mathrm{OCO}_{\text {asym }}$ and $\nu \mathrm{OCO}_{\text {sym }}$, modes of surface coordinated bidentate carbonate species on the $\mathrm{ZrO}_{2}$ support, respectively [57]. Furthermore, negative vibrational features appearing at 2987 and $2876 \mathrm{~cm}^{-1}$ can be readily assigned to the loss of $-\mathrm{CH}_{2}$ and $-\mathrm{CH}_{3}$ functionalities from the RhZr catalyst surface [58,59]. Thus, it is clear that $5 \mathrm{~h}$-spent RhZr catalyst was subject to severe coke deposition where a large variety of $\mathrm{C}_{\mathrm{x}} \mathrm{H}_{\mathrm{y}} \mathrm{O}_{\mathrm{z}}$ surface species covered both $\mathrm{Rh} / \mathrm{Rh}^{+}$active sites as well as the $\mathrm{ZrO}_{2}$ support. Lack of formation of significant amount of additional $-\mathrm{OH}$ species (except the weak signal at $3680 \mathrm{~cm}^{-1}$ ) on $5 \mathrm{~h}$-spent $\mathrm{RhZr}$ upon hydrogen treatment also points to the fact that most of the $\mathrm{ZrO}_{2}$ domains of the $5 \mathrm{~h}$-spent $\mathrm{RhZr}$ catalyst was initially covered with coke and atomic hydrogen species were not able to access surface $\mathrm{O}^{2-}$ sites to form $-\mathrm{OH}$ functionalities even after gasification.

\subsubsection{Ex-situ Raman spectroscopic experiments}

In an attempt to further elucidate the structural properties of the fresh (i.e. reduced) and spent $\mathrm{RhZr}$ and RhCe catalysts (after $5 \mathrm{~h}$ reaction at $750{ }^{\circ} \mathrm{C}, \mathrm{CO}_{2} / \mathrm{G}=4$, residence time $=3.75 \mathrm{mg} \cdot \mathrm{min} / \mathrm{Nml}$, we performed ex-situ Raman spectroscopic analysis of these catalysts as shown in Fig. 6a and b, respectively.

Topmost (black) spectrum in Fig. 6a belongs to the fresh RhZr catalyst. The feature at $173 \mathrm{~cm}^{-1}$ can be attributed to $\mathrm{RhO}_{\mathrm{x}}$ species [60-62]. This observation is in line with the in-situ FTIR data given in Fig. 4 indicating the presence of oxidic Rh species (i.e. $\mathrm{Rh}^{+}$). Six other Raman signals were also discernible in this spectrum at 211, 325, 367, 468, 548 and $611 \mathrm{~cm}^{-1}$. Among these features, while 325, 468, $611 \mathrm{~cm}^{-1}$ can be ascribed to tetragonal- $\mathrm{ZrO}_{2}$ structures, 211, 367 and $548 \mathrm{~cm}^{-1}$ can be attributed to the characteristic features of monoclinic$\mathrm{ZrO}_{2}$ [63-67].

The middle (red) Raman spectrum in Fig. 6a was obtained for the 5 h-spent RhZr catalyst. Observation of an extremely intense oblique baseline in this spectrum is a clear indication of fluorescence due to the presence of coke deposition on the $5 \mathrm{~h}$-spent RhZr catalyst. This strong fluorescence signal overwhelms most of the Raman signatures, rendering them poorly discernible. In order to remove coke deposition (at least by a certain extent), we performed photoleaching by increasing the laser power and irradiating the $5 \mathrm{~h}$-spent RhZr catalyst using the excitation laser of the Raman spectrometer. Bottommost (blue) spectrum in Fig. 6a obtained after this process possesses almost all of the characteristic $\mathrm{RhO}_{\mathrm{x}}$ and $\mathrm{ZrO}_{2}$ Raman signals present for the fresh $\mathrm{RhZr}$ catalyst suggesting that most of the coke deposit could be removed by photoleaching. These ex-situ Raman experiments (along with the supporting in-situ FTIR data in Fig. 4) clearly indicate that RhZr catalyst suffered from severe coking during the GDR reaction.

Fig. 6b shows ex-situ Raman spectra of the fresh and 5 h-spent RhCe catalyst. The most characteristic Raman signal for the stoichiometric $\mathrm{CeO}_{2}$ lattice is located at ca. $463 \mathrm{~cm}^{-1}$ associated with the $F_{2 g}$ mode of the cubic fluorite- structure (i.e. symmetric breathing mode of the oxide ions around cerium(IV) ions) $[55,68,69]$. The most prominent Raman signal for the fresh RhCe catalyst appeared at $454 \mathrm{~cm}^{-1}$ which was redshifted by $9 \mathrm{~cm}^{-1}$ with respect to the stoichiometric ceria. Such a shift was also observed in numerous former reports and was ascribed to the ceria unit cell expansion due to reduction of some of the $\mathrm{Ce}^{4+}$ ions in the ceria lattice to $\mathrm{Ce}^{3+}$. In addition to this intense feature, fresh RhCe catalyst also presented weaker and broader features at 240 and $571 \mathrm{~cm}^{-1}$ which can be assigned to oxygen vacancies and defects in the $\mathrm{CeO}_{2}$ lattice leading to a sub-stoichiometric structure. These defects can either originate from $\mathrm{Rh}$ incorporation into the ceria lattice due to strong metal support interaction between $\mathrm{Rh}$ particles and the reducible $\mathrm{CeO}_{2}$ lattice [70-74] or from the reduction of ceria with hydrogen 

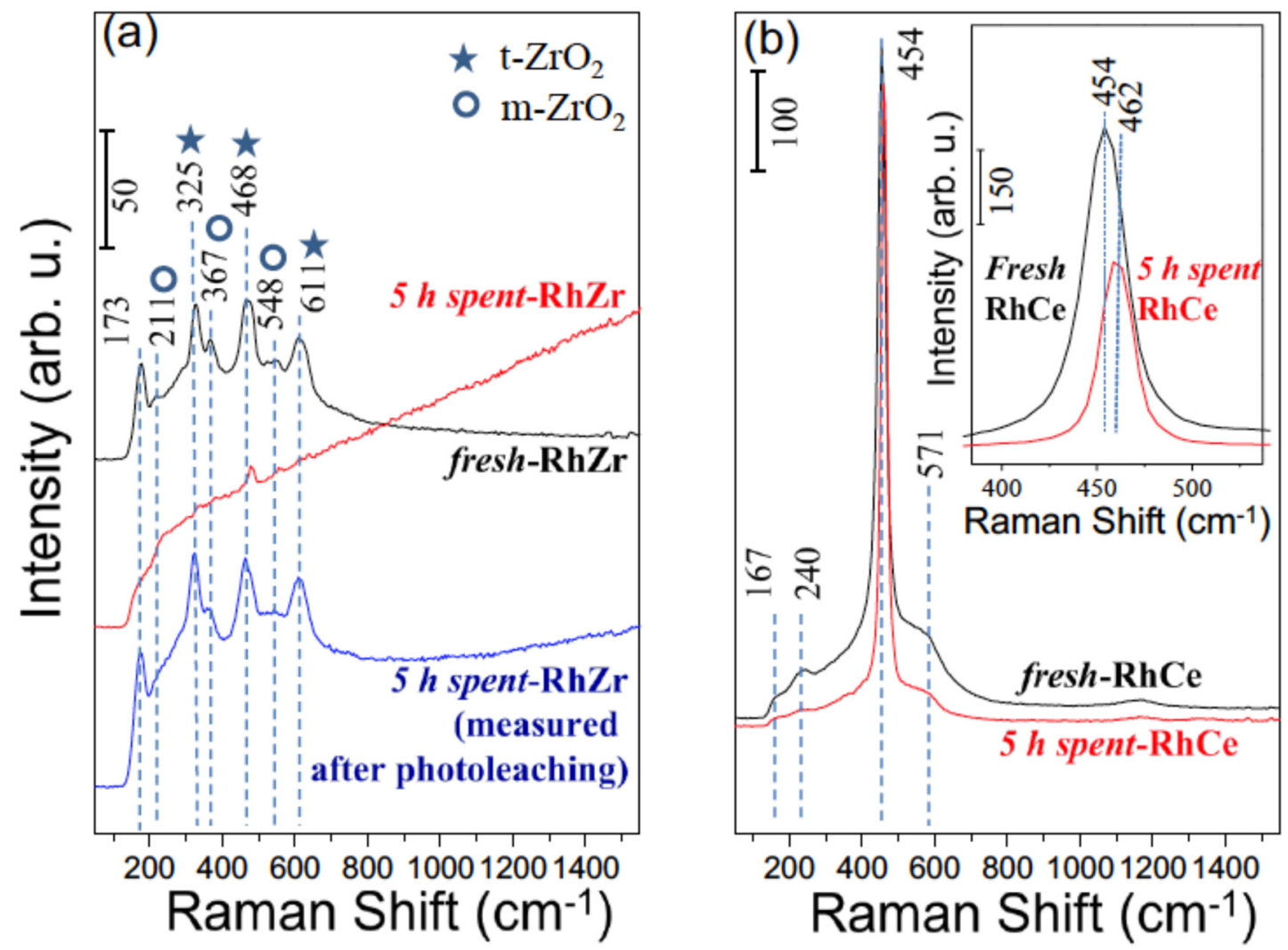

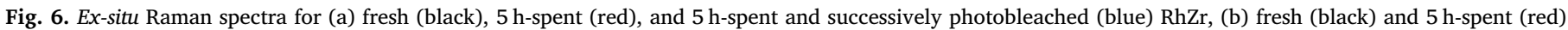
RhCe catalysts. (For interpretation of the references to colour in this figure legend, the reader is referred to the web version of this article).



Fig. 7. Effect of reaction temperature on (a) glycerol conversion,

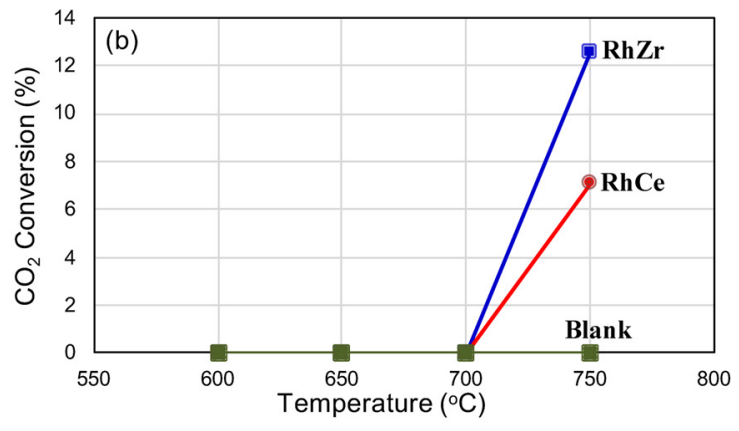

(b) $\mathrm{CO}_{2}$ conversion $\left(\mathrm{CO}_{2} / \mathrm{G}=1\right.$, residence time $\left.=0.5 \mathrm{mg} \mathrm{min} / \mathrm{Nml}\right)$. which was used during the routine activation protocol of the fresh catalysts after synthesis. Moreover, another weak feature appearing at $167 \mathrm{~cm}^{-1}$ for the Raman spectrum of the fresh RhCe catalyst can be due to the defects in the ceria lattice or possibly to $\mathrm{Rh}-\mathrm{O}-\mathrm{Ce}$ and/or $\mathrm{RhO}_{\mathrm{x}}$ species [60-62,72,73].

It can be readily seen in Fig. $6 \mathrm{~b}$ that $5 \mathrm{~h}$-spent RhCe catalyst did not reveal any fluorescence due to lack of coke deposit on this surface under GDR reaction conditions. On the other hand, it should be pointed out that there were significant changes in the spectral line shape of the Raman signals for RhCe after GDR reaction. Three features located at 167, 240 and $571 \mathrm{~cm}^{-1}$ were significantly suppressed after the GDR reaction. It is likely that this was caused by the by the healing of the oxygen vacancies and defects in the substoichiometric $\mathrm{CeO}_{2-\mathrm{x}}$ structure and oxidation to $\mathrm{CeO}_{2}$. This oxidation phenomenon is consistent with the frequency shift of the $F_{2 g}$ mode to $462 \mathrm{~cm}^{-1}$ after the GDR reaction, presumably through a mechanism resembling to the Mars-van Krevelen type. Under GDR conditions, carbon deposits on the RhCe surface could be oxidized by the utilization of mobile/active lattice oxide ions whose formation was also facilitated by $\mathrm{Rh}$ incorporation weakening the $\mathrm{Ce}-\mathrm{O}$ bond $[75,76]$.

\subsection{Catalytic activity and stability studies}

\subsubsection{Effect of reaction temperature}

Glycerol is a thermally unstable molecule, which tends to decompose at elevated temperatures [14]. It is worth mentioning that noncatalytic/homogenous decomposition of glycerol was often ignored in various former GDR studies in the literature, which resulted in inaccurate determination of catalytic conversion values [17-22]. Thus, in order to emphasize this important aspect and to distinguish the relative extents of catalytic and non-catalytic glycerol conversion routes, we performed detailed blank experiments. Effect of reaction temperature on glycerol conversion to gaseous products over RhZr and RhCe catalysts as well as in the blank experiments (i.e. without any catalysts) is presented in Fig. 7a. These results showed that homogeneous breakdown of glycerol was promoted with increasing temperature. At $600{ }^{\circ} \mathrm{C}$, glycerol conversion to gaseous product in the blank tests was found to be $7 \%$, which increased up to $38 \%$ at $750{ }^{\circ} \mathrm{C}$. It is also apparent that at 
$\mathrm{T} \leq 650^{\circ} \mathrm{C}$ and in the presence of RhZr or RhCe catalysts; no significant change in the glycerol conversion to gaseous products was observed. At $600^{\circ} \mathrm{C}$, the highest glycerol conversion was observed over RhZr, which differed from the blank test only by $6 \%$. Similarly, at $650{ }^{\circ} \mathrm{C}$, catalytic and non-catalytic glycerol conversions were found to be between $21-24 \%$ and $\sim 17 \%$, respectively. At higher temperatures, however, influence of the catalyst became notable, evident by $46 \%$ and $38 \%$ increase in glycerol conversion over RhZr (between $650-700{ }^{\circ} \mathrm{C}$ ) and RhCe (between $700-750{ }^{\circ} \mathrm{C}$ ), respectively. The difference between conversions obtained at $700{ }^{\circ} \mathrm{C}$ in favor of RhZr was associated with its higher catalytic activity due to the finer dispersion of Rh nanoparticles that was confirmed both by TEM-EDX analysis and in-situ FTIR spectroscopy studies in Sections 3.1.2 and 3.1.3, respectively. Fig. 7b shows the effect of temperature on $\mathrm{CO}_{2}$ conversion. Unlike glycerol, $\mathrm{CO}_{2}$ remained intact in the blank tests within the entire operating range. $\mathrm{CO}_{2}$ was also relatively stable in the presence of RhZr and RhCe catalysts where no $\mathrm{CO}_{2}$ conversions were observed in the $600-700{ }^{\circ} \mathrm{C}$ range. Breakdown of $\mathrm{CO}_{2}$ became noticeable at $750{ }^{\circ} \mathrm{C}$ where conversions of $12.6 \%$ and $7.1 \%$ were observed over RhZr and RhCe, respectively. Owing to the fact that at $700{ }^{\circ} \mathrm{C}$ glycerol conversion obtained on RhZr differed notably from that of the blank experiment (Fig. 7a), whereas no $\mathrm{CO}_{2}$ conversion was obtained under the same conditions (Fig. 7b), it could be stated that RhZr favored Reaction 3 only at $700^{\circ} \mathrm{C}$.

In order to interpret these findings, thermodynamic analysis was carried out to determine the natural limits of reactant conversions and product distributions under investigated reaction conditions. The analysis was carried out using the Gibbs Free Energy Reactor Unit-Op (GIBS) of CHEMCAD 7.1.4 chemical process simulation software. GIBS utilizes the Gibbs free energy minimization method provided that the inlet stream is identified. During the thermodynamic analysis, glycerol, $\mathrm{CO}_{2}, \mathrm{H}_{2}, \mathrm{CO}, \mathrm{H}_{2} \mathrm{O}, \mathrm{C}(\mathrm{s})$ as well as hydrocarbons such as methane $\left(\mathrm{CH}_{4}\right)$, ethylene $\left(\mathrm{C}_{2} \mathrm{H}_{4}\right)$, ethane $\left(\mathrm{C}_{2} \mathrm{H}_{6}\right)$, ethanol $\left(\mathrm{C}_{2} \mathrm{H}_{6} \mathrm{O}\right)$, acetaldehyde $\left(\mathrm{C}_{2} \mathrm{H}_{4} \mathrm{O}\right)$, propionaldehyde $\left(\mathrm{C}_{3} \mathrm{H}_{6} \mathrm{O}\right)$, allyl alcohol $\left(\mathrm{C}_{3} \mathrm{H}_{6} \mathrm{O}\right)$, acrolein $\left(\mathrm{C}_{3} \mathrm{H}_{4} \mathrm{O}\right)$ and acetol $\left(\mathrm{C}_{3} \mathrm{H}_{6} \mathrm{O}_{2}\right)$ were considered as the components that could exist in the product mixture, and the operating conditions existing during the activity tests were mimicked. The results clearly showed that neither of the conditions favored formation of $\mathrm{C}_{2+}$ hydrocarbons except $\mathrm{C}_{2} \mathrm{H}_{4}$ and $\mathrm{C}_{2} \mathrm{H}_{6}$, both of which existed only in trace quantities and presence of $\mathrm{C}(\mathrm{s})$ was suppressed with increasing temperature. Moreover, thermodynamic glycerol conversions, calculated based on the equilibrium amounts of the species specified in Eq. (10), showed that both catalysts were able to deliver $82 \%$ of the equilibrium glycerol conversion of $88.6 \%$ at $750{ }^{\circ} \mathrm{C}$ with RhZr being capable of delivering similar performance also at $700{ }^{\circ} \mathrm{C}$ (Fig. 7a). Thermodynamic limits of $\mathrm{CO}_{2}$ conversion at the studied reaction conditions are presented in Fig. 8. The results showed that below $700{ }^{\circ} \mathrm{C}, \mathrm{CO}_{2}$ conversion could not be achieved thermodynamically and $\mathrm{CO}_{2}$ production was favored. This is in accordance with the results of Wang et al. [15], who

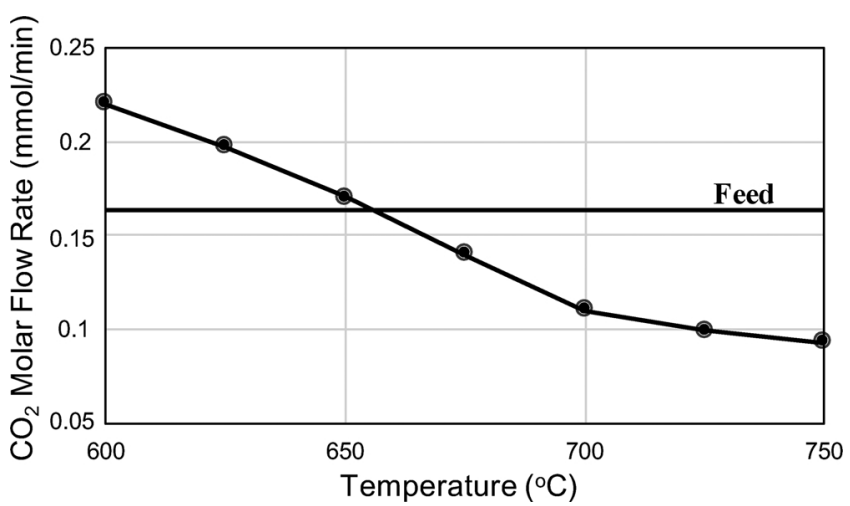

Fig. 8. Calculated thermodynamic $\mathrm{CO}_{2}$ flow rate values in the product stream as a function of temperature for the GDR reaction, where $\mathrm{CO}_{2}$ feed rate $=$ $0.16 \mathrm{mmol} / \mathrm{min}$ and $\mathrm{CO}_{2} / \mathrm{G}=1$. pointed out that $\mathrm{CO}_{2}$ conversion was thermodynamically possible only above $677^{\circ} \mathrm{C}$. Thus, it is apparent that $\mathrm{CO}_{2}$ production routes such as carbon gasification with steam (e.g. Reaction 7) was dominant at lower temperatures, whereas endothermic $\mathrm{CO}_{2}$ consumption routes (e.g. Reactions (2), (5), and (8)) were thermodynamically favored at higher temperatures.

Product distributions obtained over RhZr and RhCe catalysts as well as in the blank tests at different temperatures are presented in Fig. 9a-c, respectively. It is clearly observed that yields of $\mathrm{H}_{2}$ and $\mathrm{CO}$ were promoted with increasing temperature in all experiments. Monotonically increasing syngas yield with temperature can be explained by the facilitated decomposition of glycerol into $\mathrm{CO}$ and $\mathrm{H}_{2}$ via Reaction 3, and by steam reforming and dry reforming of $\mathrm{CH}_{4}$ (Reactions (4) and (5), respectively). Fig. 9d also provides the syngas ratios $\left(\mathrm{H}_{2} / \mathrm{CO}\right)$ obtained as a function of temperature and catalyst type. $\mathrm{H}_{2} / \mathrm{CO}$ ratio seemed to have a weak dependence on temperature and remained below 0.5 for the blank tests. However, in the presence of RhZr and RhCe catalysts, they converged to $\sim 1.1$ (i.e. very close to the ideal syngas composition of 1) upon increasing the temperature to $750{ }^{\circ} \mathrm{C}$. Increase in the $\mathrm{H}_{2} / \mathrm{CO}$ ratios in the presence of RhZr and RhCe catalysts as a function of temperature (Fig. 9d) was found to be concomitant to the corresponding changes in the $\mathrm{H}_{2}$ yields (Fig. 9a and b).

$\mathrm{CH}_{4}$ is an unwanted by-product that necessitates the post-purification of syngas. $\mathrm{CH}_{4}$ yield increased with increasing temperature both in the presence and absence of a catalyst. Increase in $\mathrm{CH}_{4}$ yield, however, was more notable at temperatures below $700{ }^{\circ} \mathrm{C}$, above which the rate of change decreased significantly on both RhZr and RhCe. For example, rate of increase in $\mathrm{CH}_{4}$ yield between $650-700{ }^{\circ} \mathrm{C}$ and $700-750{ }^{\circ} \mathrm{C}$ was $65 \%$ and $11 \%$, respectively on $\mathrm{RhZr}$, and $78 \%$ and $13 \%$, respectively, on RhCe (Fig. 9a and b). Conversion of $\mathrm{CO}$ and $\mathrm{H}_{2}$, both of which already existed in the product mixture as a result of glycerol decomposition (Reaction 3), into $\mathrm{CH}_{4}$ via reverse of Reaction 4 seemed to be the main route of $\mathrm{CH}_{4}$ production. Faster increase in $\mathrm{CH}_{4}$ yield below $700{ }^{\circ} \mathrm{C}$ was in alignment with thermodynamics, which promoted exothermic $\mathrm{CH}_{4}$ formation at lower temperatures, and with the lack of steam due to the limited impact of endothermic RWGS. The suppressed rate of increase in $\mathrm{CH}_{4}$ yields above $700{ }^{\circ} \mathrm{C}$ was likely to be caused primarily by a shift in the direction of Reaction 4 (i.e. in favor of steam reforming of methane) and by the onset of Reaction 5 . These argument were supported by the facts that $\mathrm{CO}_{2}$ (dry) reforming and steam reforming of $\mathrm{CH}_{4}$, both of which are endothermic, started to become thermodynamically significant above 650 and $620^{\circ} \mathrm{C}$, respectively [77], and steam needed to drive Reaction 4 in forward direction was provided at higher temperatures under operando conditions via RWGS, which was also endothermic and promoted at elevated temperatures. The suggested pathway seemed to hold for explaining $\mathrm{C}_{2} \mathrm{H}_{4}$ and $\mathrm{C}_{2} \mathrm{H}_{6}$ yields, both of which increased with temperature and decreased significantly above $700{ }^{\circ} \mathrm{C}$ on both RhZr and RhCe. In contrast with the catalytic experiments, dampening effect of temperature between 700 and $750^{\circ} \mathrm{C}$ on hydrocarbon yields was much less in blank runs (Fig. 9a-c). This finding would confirm that RWGS, which supplied steam needed for hydrocarbon consumption via reforming, occurred only in the presence of RhZr or RhCe, and the extent of homogeneous $\mathrm{CO}_{2}$ reforming of hydrocarbons was significantly smaller than that obtained heterogeneously.

Reaction temperature dictated the extent of coking in GDR [78]. Coke formation was inhibited at elevated temperatures due to the endothermic carbon gasification routes (Reactions 6-8) and became thermodynamically unfavorable above $700{ }^{\circ} \mathrm{C}$ for $\mathrm{CO}_{2} / \mathrm{G}=1$. A visual proof of coking hindrance at elevated temperatures was presented in Fig. 10 revealing images of the catalyst bed $\left(\mathrm{RhZr}+\alpha-\mathrm{Al}_{2} \mathrm{O}_{3}\right)$ taken after $5 \mathrm{~h}$ testing at different temperatures. It can be observed that the extent of coke deposition decreased with temperature, as verified by the color of the bed becoming progressively lighter from 600 to $750{ }^{\circ} \mathrm{C}$. Apart from temperature, both the extent and nature of coke formation depended also strongly on the catalyst type, as illustrated by the in-situ 



Temperature $\left({ }^{\circ} \mathrm{C}\right)$

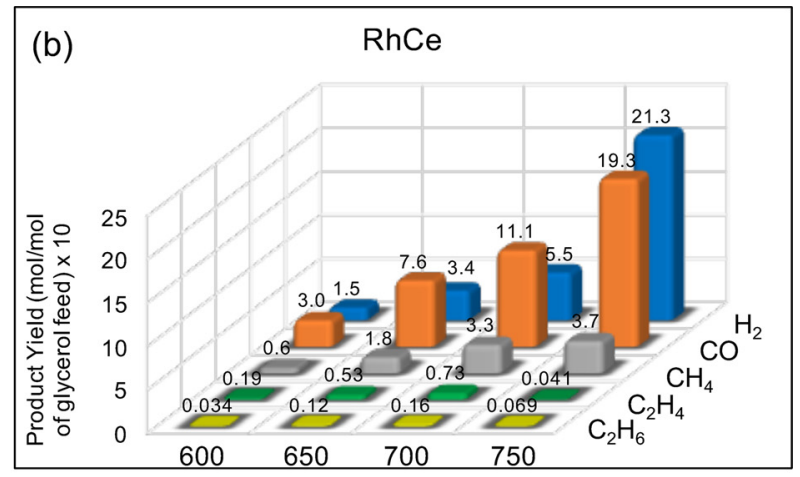

(d)



Temperature $\left({ }^{\circ} \mathrm{C}\right)$

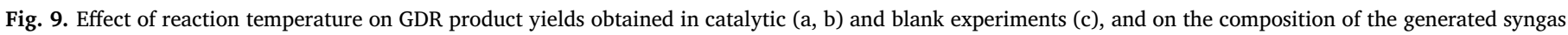
(d). $\left(\mathrm{CO}_{2} / \mathrm{G}=1\right.$, residence time $\left.=0.5 \mathrm{mg} \cdot \mathrm{min} / \mathrm{Nml}\right)$.

FTIR spectroscopic results presented in Figs. 4-6.

Results discussed above suggest that elevated temperatures (e.g. $750^{\circ} \mathrm{C}$ ) could be favorable in GDR on RhZr and RhCe catalysts as they lead to the suppression of coke formation. However, it should be noted that extremely high temperatures also may result in catalyst aging via sintering of the Rh active sites. The likelihood of this phenomenon can be assessed by checking the Hüttig and Tamman temperatures of the currently utilized support materials corresponding to 0.3 and 0.5 times their melting temperatures, respectively. It is reported that at Hüttig temperature, atoms in the lattice defects become mobile, while at Tamman temperature atoms at the bulk start to demonstrate mobility causing rearrangement and sintering of the active metals [79]. By considering bulk melting points, Hüttig and Tamman temperatures of $\mathrm{CeO}_{2}$ and $\mathrm{ZrO}_{2}$ can be estimated to be 720 and $812.7^{\circ} \mathrm{C}$ and 1200 and $1354.5^{\circ} \mathrm{C}$, respectively $[79,80]$. Based on these findings, default value of the GDR reaction temperature was chosen to be $750{ }^{\circ} \mathrm{C}$, which secured the thermal stability of the support materials and was used in the rest of the performance tests where the effects of $\mathrm{CO}_{2} / \mathrm{G}$ ratio and the residence time were explored. Even though it slightly exceeded Hüttig temperature of $\mathrm{CeO}_{2}, 750^{\circ} \mathrm{C}$ was significantly below the related Tamman temperature $\left(1200^{\circ} \mathrm{C}\right)$. Moreover, as the supports materials were already calcined at $800^{\circ} \mathrm{C}$ for $4 \mathrm{~h}$ prior to their use in catalyst preparation, no changes in their structure were expected during the reactions carried out at $750{ }^{\circ} \mathrm{C}$.

\subsubsection{Effect of $\mathrm{CO}_{2} / \mathrm{G}$ ratio}

In order to observe the effect of $\mathrm{CO}_{2}$ concentration in the feed, $\mathrm{CO}_{2} /$ $\mathrm{G}$ ratios between 1 and 4 were tested at $750{ }^{\circ} \mathrm{C}$. Experiments in the absence of $\mathrm{CO}_{2}$ in the feed $\left(\mathrm{CO}_{2} / \mathrm{G}=0\right)$ were also conducted to investigate the extent of glycerol decomposition into gaseous products. The results, presented in Fig. 11a, give a clear trend of decreasing glycerol conversion to gaseous products with increasing $\mathrm{CO}_{2}$ in the feed. The same trend characterized the relation between $\mathrm{CO}_{2} / \mathrm{G}$ ratio and thermodynamic glycerol conversions predicted by the Gibbs free energy minimization method (Section 3.2.1) and calculated by inserting equilibrium quantities of $\mathrm{H}_{2}, \mathrm{CH}_{4}, \mathrm{C}_{2} \mathrm{H}_{4}$ and $\mathrm{C}_{2} \mathrm{H}_{6}$ into Eq. (10). The findings can be explained by the negative correlation of $\mathrm{H}_{2}$ production with amount of inlet $\mathrm{CO}_{2}$ due to the occurrence of RWGS (Reaction 2). As glycerol conversion to gaseous products was dictated by $\mathrm{H}_{2}$ in the product stream (Eq. 10), its consumption by RWGS caused progressive decline of conversion with increasing $\mathrm{CO}_{2} / \mathrm{G}$, as commonly noted for both catalysts. This qualitative finding was observed also by theoretical predictions [15] and experimental studies $[17,19]$ reported in the literature. It is worth noting that Eq. (10) was based on elemental

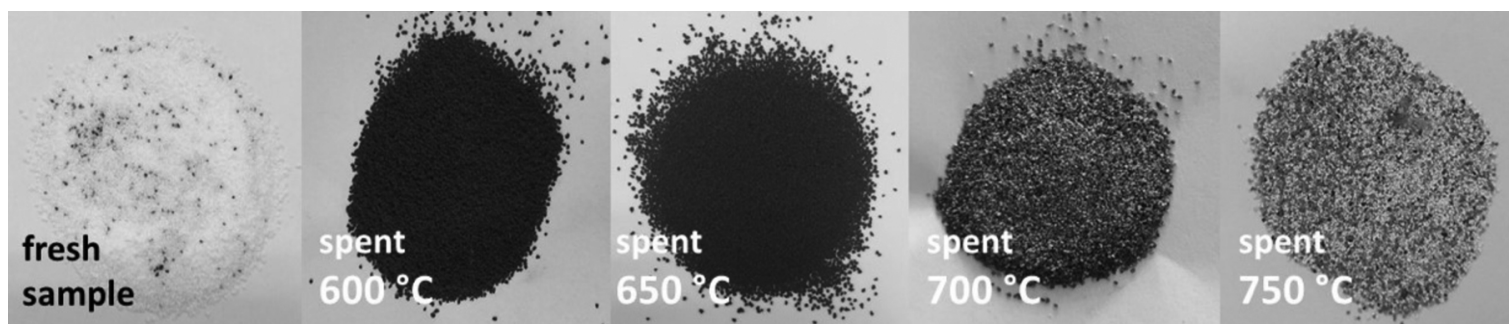

Fig. 10. Images of the catalyst powder (RhZr) mixed with $\alpha-\mathrm{Al}_{2} \mathrm{O}_{3}$ diluent before (fresh sample) and $5 \mathrm{~h}$ after the reaction as a function of GDR reaction temperature $\left(\mathrm{CO}_{2} / \mathrm{G}=1\right.$, residence time $\left.=0.5 \mathrm{mg} \cdot \mathrm{min} / \mathrm{Nml}\right)$. 



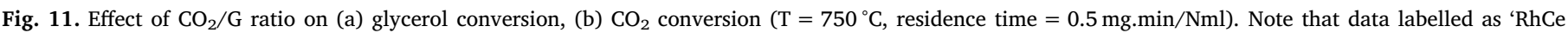
Modified' in Fig. 11a was calculated by assuming that all of the converted $\mathrm{CO}_{2}$ is spent in $\mathrm{RWGS}$ to produce $\mathrm{H}_{2} \mathrm{O}$.

hydrogen balance over the gaseous species and did not include $\mathrm{H}_{2} \mathrm{O}$, which was condensed in the cold traps and removed from the reactor outlet stream before GC analysis. Since RWGS produces $\mathrm{H}_{2} \mathrm{O}$ while consuming $\mathrm{H}_{2}$, the lack of $\mathrm{H}_{2} \mathrm{O}$ in the definition of Eq. (10) leads to the prediction of lower glycerol conversions together with their notable decline at higher amounts of inlet $\mathrm{CO}_{2}$. In order to test the impact of the absence of $\mathrm{H}_{2} \mathrm{O}$ on the results, it was assumed that all of the converted $\mathrm{CO}_{2}$ was spent in RWGS to produce $\mathrm{H}_{2} \mathrm{O}$ which was included in the hydrogen balance to calculate so called "modified" glycerol conversions. In other words, $\mathrm{H}_{2} \mathrm{O}$ was assumed to remain within the product mixture without being consumed. Fig. 11a presents the "modified" glycerol conversion with respect to $\mathrm{CO}_{2} / \mathrm{G}$ ratio over $\mathrm{RhCe}$. It is seen in Fig. 11a that there is a less steep, but still decreasing trend for "modified" glycerol conversion upon increasing $\mathrm{CO}_{2} / \mathrm{G}$ ratio. Owing to the fact that the "modified" case is somewhat extreme in the sense that $\mathrm{H}_{2} \mathrm{O}$ is consumed primarily by its reaction with $\mathrm{CH}_{4}$ (Reaction 4) [40], it can be concluded that the absence of $\mathrm{H}_{2} \mathrm{O}$ in Eq. (10) will not affect the qualitative trends reported in Fig. 11a. The results also showed that both catalysts delivered more than $\sim 80 \%$ approach to equilibrium glycerol conversions under all conditions. The clear impact of catalysts on glycerol consumption was evident by the blank tests which gave homogeneous conversions of $\sim 38 \%$ to gaseous products regardless of the $\mathrm{CO}_{2} / \mathrm{G}$ ratio.

The effect of $\mathrm{CO}_{2} / \mathrm{G}$ ratio on $\mathrm{CO}_{2}$ conversion is presented in Fig. 11b. These results show that, at all feed ratios, RhZr delivered $\mathrm{CO}_{2}$ conversions that were higher than those obtained over RhCe. Superiority of RhZr was also valid for glycerol conversions reported in Fig. 11a. Lower glycerol and $\mathrm{CO}_{2}$ conversions measured over RhCe catalyst can be attributed to the strong metal-support interaction (SMSI), suppressing the activity of the Rh sites on RhCe. As demonstrated in detail by the in-situ FTIR studies (Fig. 4), the strong interaction between $\mathrm{CeO}_{2}$ and $\mathrm{Rh}$ leads to ceria phase to cover/encapsulate $\mathrm{Rh}$ sites, reducing the access of reactants and removal of products, which in turn result in lower conversions.

Fig. $11 \mathrm{~b}$ also suggests that, on both catalysts, $\mathrm{CO}_{2}$ conversion increases upon increasing $\mathrm{CO}_{2} / \mathrm{G}$ ratio from 1 to 2 but remains almost unchanged at higher feed ratios. In contrast, product distributions presented in Fig. 12 indicates catalyst specific responses (i.e. differences) as a function of $\mathrm{CO}_{2} / \mathrm{G}$. It is evident that upon increasing $\mathrm{CO}_{2} / \mathrm{G}$ ratio, while $\mathrm{H}_{2}$ yield decreased, $\mathrm{CO}$ yield increased over both catalysts. This trend, however, was clearly absent in the blank tests carried out under identical conditions. Moreover, addition of $\mathrm{CO}_{2}$ (i.e. increasing $\mathrm{CO}_{2} / \mathrm{G}$ from 0 to 1) led to significant changes in $\mathrm{H}_{2}$ and $\mathrm{CO}$ yields, which was not the case for the blank tests. These findings can be attributed to the occurrence of catalytic RWGS (Reaction 2). Within $\mathrm{CO}_{2}$ / $\mathrm{G}=1-3$, both catalysts exhibited common trends revealing decreasing $\mathrm{C}_{1}-\mathrm{C}_{2}$ hydrocarbon yields (Fig. 12). Higher feed ratios favored RWGS producing higher amounts of $\mathrm{H}_{2} \mathrm{O}$. Thus, increasing levels of steam in the presence of $\mathrm{CO}_{2}$ consumed $\mathrm{CH}_{4}, \mathrm{C}_{2} \mathrm{H}_{6}$ and $\mathrm{C}_{2} \mathrm{H}_{4}$ via reforming routes (Reactions 4 and 5). Higher yields of $\mathrm{H}_{2}$ and $\mathrm{CO}$, and lower yields of $\mathrm{C}_{1}$ -
$\mathrm{C}_{2}$ hydrocarbons within $\mathrm{CO}_{2} / \mathrm{G}=1-3$ suggest that catalytic activity of the RhZr surpasses that of RhCe under the given experimental conditions.

However, trends regarding the relative activities of $\mathrm{RhZr}$ and $\mathrm{RhCe}$ catalysts were reversed for $\mathrm{CO}_{2} / \mathrm{G}=3-4$ (Fig. 12). Under such conditions, $\mathrm{CH}_{4}$ yields remained almost constant for $\mathrm{RhZr}$, but continued to decrease on RhCe. Similarly, $\mathrm{C}_{2} \mathrm{H}_{6}$ yield slightly increased on RhZr, but kept decreasing on RhCe. These differences indicated that at higher $\mathrm{CO}_{2} / \mathrm{G}$ ratios, RhZr started to lose its activity, while RhCe remained active. This was also verified by the current in-situ FTIR and ex-situ Raman characterization data illustrating that RhZr was subject to sintering and carbon deposition in a relatively severe manner, while such phenomena occurred to a lesser extent on RhCe (Figs. 4-6). These findings reveal valuable insights regarding the structure-functionality relationships associated with the currently investigated GDR catalysts. It is likely that $\mathrm{Rh}$ particles have a relatively higher surface mobility on the $\mathrm{ZrO}_{2}$ support material with respect to that of $\mathrm{CeO}_{2}$ due to the relatively weaker metal-support interaction in the former case. Hence, sintering of the currently used catalysts was presumably triggered hydrothermally by the co-existence of high temperatures and steam, where the latter was generated by the RWGS reaction occurring under $\mathrm{CO}_{2}$-rich feed conditions. Therefore, even though RWGS favored the consumption of $\mathrm{CO}_{2}$, it also facilitated sintering. These two distinct phenomena could be responsible for the $\mathrm{CO}_{2}$ conversions to remain unchanged in the $\mathrm{CO}_{2} / \mathrm{G}$ range of 2-4 (Fig. 11b) for RhZr. On the other hand, the strong metal-support interaction present on RhCe limited the surface mobility of the Rh sites and inherently protected the Rh particles against sintering which resulted in high activity even at high $\mathrm{CO}_{2} /$ $\mathrm{G}$ ratios. Moreover, the superior oxygen-transfer capability of $\mathrm{CeO}_{2}$ lattice expedited the gasification of the surface carbon deposit in to gaseous $\mathrm{CO}$ and/or $\mathrm{CO}_{2}[33,34]$. This argument is in very good agreement with the current Raman spectroscopic results (Fig. 6) indicating lack of significant amount of carbonaceous species over RhCe. In this context, relatively invariant $\mathrm{CO}_{2}$ concentrations observed on RhCe catalyst can be attributed to opposing effects of $\mathrm{CO}_{2}$ consumption via RWGS and efficient oxidation/gasification of the surface carbon species into $\mathrm{CO}_{2}$. Higher RWGS activity of RhCe at $\mathrm{CO}_{2} / \mathrm{G}$ between 3 and 4 was correlated with the rate of decrease in glycerol conversion, which was higher than that observed on $\mathrm{RhZr}$ in the specified $\mathrm{CO}_{2} / \mathrm{G}$ range (Fig. 11a). Due to its presence in Eq. (10), increased $\mathrm{H}_{2}$ consumption at higher catalytic activity towards RWGS caused glycerol conversion to decrease. The blank experiments that involved testing of pure $\mathrm{ZrO}_{2}$ and $\mathrm{CeO}_{2}$ supports at $750{ }^{\circ} \mathrm{C}$ and $\mathrm{CO}_{2} / \mathrm{G}=4$ (i.e. the conditions that maximized $\mathrm{CO}_{2}$ consumption in catalytic experiments) did not give any $\mathrm{CO}_{2}$ conversions. These findings showed that support-specific differences in the responses of the catalysts were observed only in the presence of Rh.

The results presented in Fig. $11 \mathrm{~b}$ also include the evolution of thermodynamic $\mathrm{CO}_{2}$ conversion as a function of $\mathrm{CO}_{2} / \mathrm{G}$ ratio. It is apparent that experimental and theoretical conversion values are notably different from each other. This dissimilarity can be due to the short 



Fig. 12. Effect of $\mathrm{CO}_{2} / \mathrm{G}$ on GDR product yields obtained in catalytic (a, b) and blank experiments (c), and on the composition of the generated syngas (d). $\left(\mathrm{T}=750^{\circ} \mathrm{C}\right.$, residence time $\left.=0.5 \mathrm{mg} \cdot \mathrm{min} / \mathrm{Nml}\right)$.

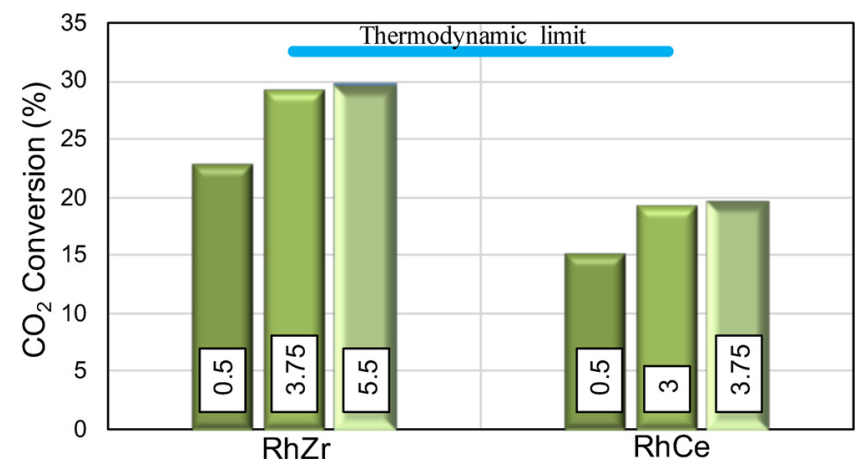

Fig. 13. $\mathrm{CO}_{2}$ conversion obtained at different residence times in terms of mg.min $/ \mathrm{Nml}\left(\mathrm{T}=750{ }^{\circ} \mathrm{C}\right.$ and $\left.\mathrm{CO}_{2} / \mathrm{G}=4\right)$.

residence time ( $0.5 \mathrm{mg} \cdot \mathrm{min} / \mathrm{Nml})$ involved in the current experiments. In order to test this hypothesis, additional experiments were conducted at longer residence times which was achieved by increasing the amount of catalyst packed in the reactor while keeping the total flow rate constant at $40 \mathrm{Nml} / \mathrm{min}$. These results, presented in Fig. 13, showed that, upon changing the residence time from 0.5 to $3.75 \mathrm{mg} . \mathrm{min} / \mathrm{Nml}$, $\mathrm{CO}_{2}$ conversion on $\mathrm{RhZr}$ increased from $22.9 \%$ to $29.2 \%$. A further increase in residence time to $5.5 \mathrm{mg} . \mathrm{min} / \mathrm{Nml}$, however, led to a limited change in conversion to $29.5 \%$. In other words, $\mathrm{CO}_{2}$ conversion converged to the thermodynamic limit of $32.6 \%$. A similar trend was also observed for RhCe, though the relative conversion values were less than that of RhZr.

Owing to the fact that it was reported in neither of studies in the literature on Ni-driven GDR, $\mathrm{CO}_{2}$ conversion could not be used as a metric for comparison of RhZr and RhCe catalysts with the Ni-based counterparts. In this respect, the results presented in Figs. $7 \mathrm{~b}$ and Figure $11 \mathrm{~b}$ were unique in the literature in terms of reporting $\mathrm{CO}_{2}$ conversions under GDR conditions. Comparisons made on the basis of glycerol conversions calculated by the methodology followed in Eq. (10) showed that, even though they were tested at much shorter residence times, both RhZr and RhCe outperformed Ni-based catalysts. For example, glycerol conversion of $80 \%$ was reported on $20 \% \mathrm{Ni} /$ cement clinker (CC: $\mathrm{CaO}+\mathrm{MgO}$ ) catalyst at $750^{\circ} \mathrm{C}, \mathrm{CO}_{2} / \mathrm{G}=1.67$ and residence time of $\sim 1.5 \mathrm{mg} . \mathrm{min} / \mathrm{Nml}$ [21], whereas more than $65 \%$ of glycerol was converted on RhZr and RhCe under the same temperature and feed composition, but with a shorter residence time of $0.5 \mathrm{mg} \cdot \mathrm{min} / \mathrm{Nml}$ (Fig. 11a). Moreover, glycerol conversions remained below $\sim 30 \%$ on $15 \% \mathrm{Ni} / \mathrm{CaO}, 10 \% \mathrm{Ni} / \mathrm{ZrO}_{2}$ and $5 \% \mathrm{Ag}-15 \% \mathrm{Ni} / \mathrm{SiO}_{2}$ catalysts at $700{ }^{\circ} \mathrm{C}$, $\mathrm{CO}_{2} / \mathrm{G}=1$, and residence times $\sim 10$ times higher than involved in the present work [23,24]. At the same temperature and $\mathrm{CO}_{2} / \mathrm{G}$, however, RhZr and RhCe catalysts gave glycerol conversions of $70 \%$ and $35 \%$, respectively (Fig. 7a).

\subsubsection{Catalyst stability}

Stability of the catalysts were examined through $72 \mathrm{~h}$ time-onstream (TOS) tests carried out at $750{ }^{\circ} \mathrm{C}, \mathrm{CO}_{2} / \mathrm{G}=4$ and residence time of $3.75 \mathrm{mg} . \mathrm{min} / \mathrm{Nml}$. Outcomes presented in Fig. 14a showed that even though RhCe delivered lower $\mathrm{CO}_{2}$ conversions, it exhibited superior stability as compared to RhZr. At the end of $72 \mathrm{~h}, \mathrm{CO}_{2}$ conversion of RhZr decreased from $29 \%$ to $17.5 \%$, which corresponded to a $40 \%$ conversion loss. In contrast, corresponding loss in conversion was only $23 \%$ for RhCe. Due to the dissimilar rates of deactivation, conversion gap between RhZr and RhCe catalysts monotonically diminished. Comparison of the $\mathrm{CH}_{4}$ production rates, shown in Fig. 14b, also provides insight regarding differences in catalytic deactivation. While the fresh $\mathrm{RhZr}$ did not produce $\mathrm{CH}_{4}$, its throughput reached to $\sim 0.8 \mathrm{Nml}$ / min at the end of $72 \mathrm{~h}$. In the same time span, however, $\mathrm{CH}_{4}$ production rate increased by only $\sim 0.6 \mathrm{Nml} / \mathrm{min}$ on $\mathrm{RhCe}$. As $\mathrm{CH}_{4}$ consumption was primarily due to the catalytic reforming routes, existence of $\mathrm{CH}_{4}$ in the product stream can be linked to reduced catalytic activity. Along these lines, it is apparent that RhZr deactivated faster than RhCe. Deactivation also suppressed the syngas production rate over both catalysts (Fig. 14c). However, $\mathrm{H}_{2} / \mathrm{CO}$ ratios remained almost invariant (i.e. stayed within $\mathrm{H}_{2} / \mathrm{CO} \sim 0.66$ and 0.8 ) on both catalysts. 

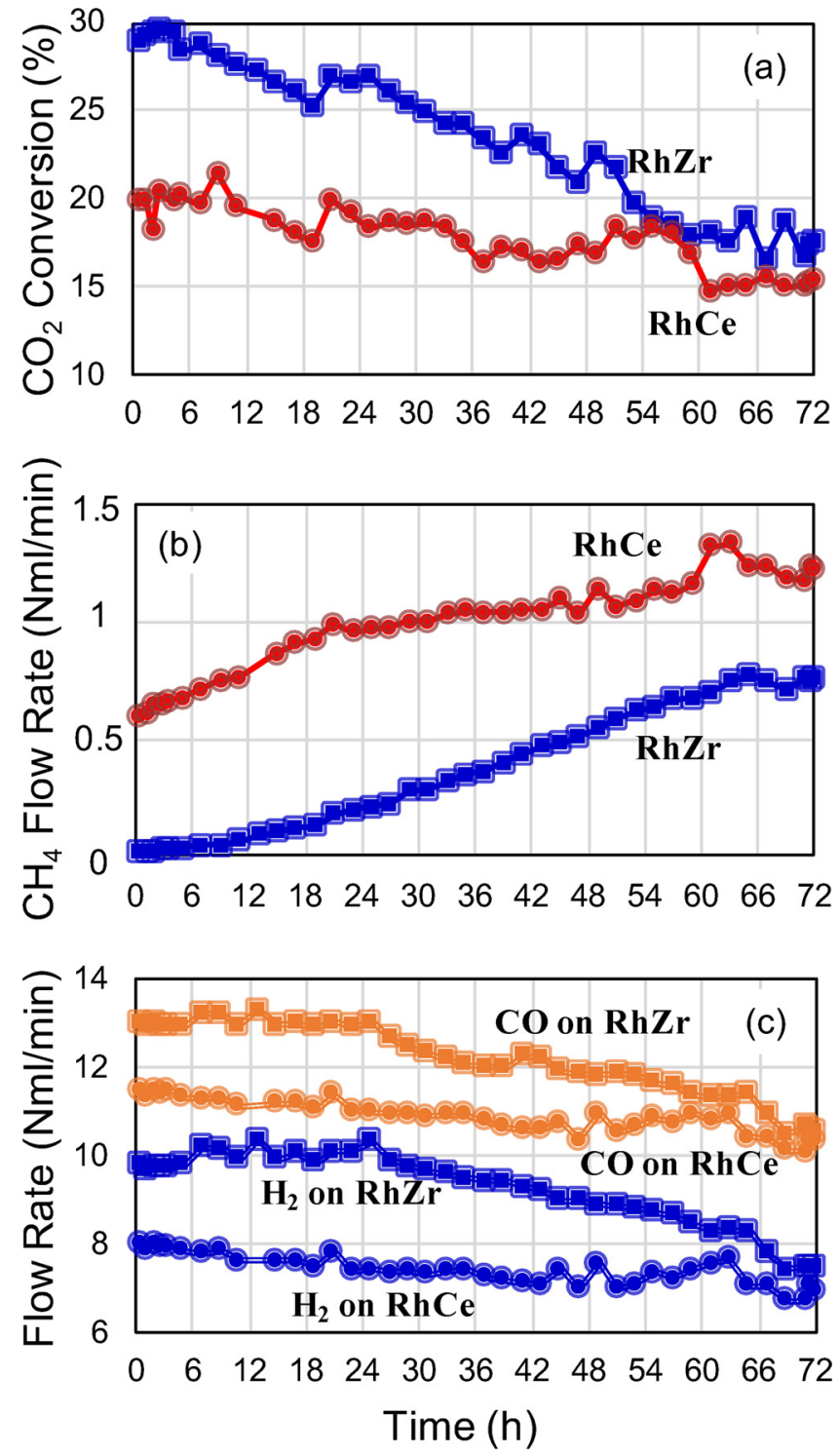

Fig. 14. (a) $\mathrm{CO}_{2}$ conversions, (b) $\mathrm{CH}_{4}$ flow rates, and (c) $\mathrm{H}_{2}$ and $\mathrm{CO}$ flow rates obtained in TOS testing of RhZr and RhCe catalysts.

The absence of catalyst stability in terms of $\mathrm{CO}_{2}$ conversion in the GDR literature prevents benchmarking of the stability of the RhZr and RhCe catalysts provided in Fig. 14. Limited number of studies in the literature involved $72 \mathrm{~h}$ TOS testing of $3 \% \mathrm{La}-20 \% \mathrm{Ni} / \mathrm{Al}_{2} \mathrm{O}_{3}$ and $20 \%$ $\mathrm{Ni} / \mathrm{CC}$ catalysts only in terms of glycerol conversion, which decreased by $\sim 25 \%$ and $>\sim 50 \%$ respectively $[17,21]$. Interpretation of catalyst stability using glycerol conversion, however, is somewhat questionable as it does not reflect the inherent stability of the catalysts due to the presence of homogeneous reactions. The lack of contribution of noncatalytic reactions to the breakdown of glycerol in the literature also makes the reported outcomes of the TOS experiments debatable. Despite these uncertainties, RhZr and RhCe catalysts delivered truly stable glycerol conversions, which changed only by $<4 \%$ on both catalysts at the end of $72 \mathrm{~h}$ (data not shown) and clearly outperformed the Ni-based counterparts.

\section{Conclusions}

Syngas formation by dry reforming of glycerol was investigated on ceria and zirconia supported Rh-based catalysts in a series of activity and stability tests, and characterization studies. Conversion of glycerol started at $600{ }^{\circ} \mathrm{C}$, increased with temperature and reached up to $76 \%$ and $72 \%$ at $750{ }^{\circ} \mathrm{C}$ on $\mathrm{Rh} / \mathrm{ZrO}_{2}$ and $\mathrm{Rh} / \mathrm{CeO}_{2}$, respectively. Higher temperatures were also beneficial for suppressing carbon formation and for increasing $\mathrm{H}_{2} / \mathrm{CO}$ up to $\sim 1$, the syngas composition for improving long chain hydrocarbon selectivity in Fischer-Tropsch synthesis. In accordance with the thermodynamic calculations, $\mathrm{CO}_{2}$ conversions, reported for the first time in the literature for catalytic glycerol dry reforming, were observed only above $700{ }^{\circ} \mathrm{C}$. Increasing the inlet molar $\mathrm{CO}_{2} / \mathrm{G}$ ratio from 1 to 4 led to a steady decline in glycerol conversions from $76 \%$ to $59 \%$ on $\mathrm{Rh} / \mathrm{ZrO}_{2}$ and from $72 \%$ to $52 \%$ on $\mathrm{Rh} / \mathrm{CeO}_{2}$. The same change, however, resulted in an opposite trend in $\mathrm{CO}_{2}$ conversions which first increased up to and then remained constant at $23 \%$ and $16 \%$ on $\mathrm{Rh} / \mathrm{ZrO}{ }_{2}$ and $\mathrm{Rh} / \mathrm{CeO}_{2}$, respectively. These values were improved further up to $30 \%$ on $\mathrm{Rh} / \mathrm{ZrO}_{2}$ and $20 \%$ on $\mathrm{Rh} / \mathrm{CeO}_{2}$ by increasing the residence time. Despite its higher activity, which was related to the slightly higher specific surface area and smaller average Rh-particle size, $\mathrm{Rh} / \mathrm{ZrO}_{2}$ deactivated faster than $\mathrm{Rh} / \mathrm{CeO}_{2}$ in a time span of $72 \mathrm{~h}$ at $750{ }^{\circ} \mathrm{C}$ and $\mathrm{CO}_{2} / \mathrm{G}=4$. For the first time in the literature, molecularlevel root causes of deactivation characteristics of the glycerol dry reforming catalysts were investigated by in-situ FTIR, Raman spectroscopy, transmission electron microscopy and energy dispersive X-ray analysis of the fresh and spent samples. These techniques consistently confirmed that the loss in activity in $\mathrm{Rh} / \mathrm{ZrO}_{2}$ was associated with sintering of $\mathrm{Rh}$ nanoparticles and coke formation. These phenomena, however, occurred to a remarkably lesser extent on $\mathrm{Rh} / \mathrm{CeO}_{2}$ and improved its stability due to (i) encapsulation of $\mathrm{Rh}$ nanoparticles by $\mathrm{CeO}_{2}$ as a result of strong metal-support interaction and (ii) impact of the mobile oxygen species and creation of oxygen vacancies on ceria domains that inhibited coking on the catalyst surface. Strong metal-support interaction on $\mathrm{Rh} / \mathrm{CeO}_{2}$, however, partially suppressed the catalytic activity of the metal sites.

\section{Declaration of interest}

None.

\section{Acknowledgements}

Financial support was provided by TUBITAK [grant number 117M163] and by Bogazici University Scientific Research Projects [grant number BAP-13880]. EO and ZS acknowledge the scientific collaboration with TARLA project founded by the Ministry of Development of Turkey [grant number DPT2006K-120470].

\section{References}

[1] IEA, Annual Energy Outlook 2015 with Projections to 2040, (2015).

[2] J.V. Gerpen, Fuel Process. Technol. 86 (2005) 1097-1107.

[3] R.L. Naylor, M.M. Higgins, Renew. Sustain. Energy Rev. 77 (2017) 695-705.

[4] Y.-C. Lin, Int. J. Hydrogen Energy 38 (2013) 2678-2700.

[5] C.A. Schwengber, H.J. Alves, R.A. Schaffner, F.A. da Silva, R. Sequinel, V.R. Bach, R.J. Ferracin, Renew. Sustain. Energy Rev. 58 (2016) 259-266.

[6] A. Delparish, A.K. Avci, Fuel Process. Technol. 151 (2016) 72-100.

[7] J.M. Silva, M.A. Soria, L.M. Madeira, Renew. Sustain. Energy Rev. 42 (2015) 1187-1213.

[8] N. Abatzoglou, C. Fauteux-Lefebvre, Wiley Interdiscip. Rev. Energy Environ. 5 (2016) 169-187.

[9] D. Pakhare, J. Spivey, Chem. Soc. Rev. 43 (2014) 7813-7837.

[10] A. de Klerk, Fischer-Tropsch Refining, Wiley-VCH, Weinheim, 2011.

[11] E. Simsek, M. Karakaya, A.K. Avci, Z.I. Onsan, Int. J. Hydrogen Energy 38 (2013) 870-878.

[12] G.R. Kale, B.D. Kulkarni, Fuel Process. Technol. 91 (2010) 520-530.

[13] P.M. Mortensen, I. Dybkjær, Appl. Catal. A Gen. 495 (2015) 141-151.

[14] T. Valliyappan, N.N. Bakhshi, A.K. Dalai, Bioresour. Technol. 99 (2008) $4476-4483$.

[15] X. Wang, M. Li, M. Wang, H. Wang, S. Li, S. Wang, X. Ma, Fuel 88 (2009) 2148-2153.

[16] A.C.D. Freitas, R. Guirardello, Int. J. Hydrogen Energy 39 (2014) 17969-17984.

[17] K.W. Siew, H.C. Lee, J. Gimbun, S.Y. Chin, M.R. Khan, Y.H. Taufiq-Yap, C.K. Cheng, Renew. Energy 74 (2015) 441-447.

[18] K.W. Siew, H.C. Lee, M.R. Khan, J. Gimbun, C.K. Cheng, J. Energy Chem. 24 (2015) 
$366-373$.

[19] K.W. Siew, H.C. Lee, J. Gimbun, C.K. Cheng, Int. J. Hydrogen Energy 39 (2014) 6927-6936.

[20] K.W. Siew, H.C. Lee, J. Gimbun, C.K. Cheng, J. Energy Chem. 23 (2014) 15-21.

[21] H.C. Lee, K.W. Siew, J. Gimbun, C.K. Cheng, Chem. Eng. J. 255 (2014) 245-256.

[22] H.C. Lee, K.W. Siew, M.R. Khan, S.Y. Chin, J. Gimbun, C.K. Cheng, J. Energy Chem. 23 (2014) 645-656.

[23] N.N. Mohd Arif, D.-V.N. Vo, M.T. Azizan, Bull. Chem. React. Eng. Catal. 11 (2016) 200-209.

[24] N. Harun, J. Gimbun, M.T. Azizan, S.Z. Abidin, Bull. Chem. React. Eng. Catal. 11 (2016) 220-229.

[25] A.I. Tsyganok, M. Inaba, T. Tsunoda, S. Hamakawa, K. Suzuki, T. Hayakawa, Catal. Commun. 4 (2003) 493-498.

[26] Z. Hou, T. Yashima, Catal. Lett. 89 (2003) 193-197.

[27] A.M. da Silva, K.R. de Souza, G. Jacobs, U.M. Graham, B.H. Davis, L.V. Mattos, F.B. Noronha, Appl. Catal. B 102 (2011) 94-109.

[28] A. Drif, N. Bion, R. Brahmi, S. Ojala, L. Pirault-Roy, E. Turpeinen, P.K. Seelam, R.L. Keiski, F. Epron, Appl. Catal. A Gen. 504 (2015) 576-584.

[29] K.J. Puolakka, S. Juutilainen, A.O.I. Krause, Catal. Today 115 (2006) 217-221.

[30] A.N.J. van Keulen, K. Seshan, J.H.B.J. Hoebink, J.R.H. Ross, J. Catal. 166 (1997) 306-314.

[31] S. Therdthianwong, C. Siangchin, A. Therdthianwong, Fuel Process. Technol. 89 (2008) 160-168.

[32] M.C.J. Bradford, M.A. Vannice, J. Catal. 173 (1998) 157-171.

[33] R. Wang, H. Xu, X. Liu, Q. Ge, W. Li, Appl. Catal. A Gen. 305 (2006) 204-210.

[34] P. Djinović, J. Batista, A. Pintar, Int. J. Hydrogen Energy 37 (2012) 2699-2707.

[35] X. Zheng, X. Zhang, X. Wang, S. Wang, S. Wu, Appl. Catal. A Gen. 295 (2005) $142-149$.

[36] J.G. Jakobsen, M. Jakobsen, I. Chorkendorff, J. Sehested, Catal. Lett. 140 (2010) 90-97.

[37] E. Kayhan, S.M. Andonova, G.S. Şentürk, C.C. Chusuei, E. Ozensoy, J. Phys. Chem. C 114 (2010) 357-369.

[38] Z.I. Onsan, A.K. Avci, Multiphase Catalytic Reactors: Theory, Design, Manufacturing, and Applications, Wiley, Hoboken, New Jersey, 2016.

[39] Z.I. Onsan, A.K. Avci, D. Shekhawat, J.J. Spivey, D.A. Berry (Eds.), Fuel Cells: Technologies for Fuel Processing, Elsevier Science, Amsterdam, 2011, pp. 451-516.

[40] J.R. Rostrup-Nielsen, G. Ertl, H. Knozinger, F. Schüth, J. Weitkamp (Eds.), Handbook of Heterogeneous Catalysis, Wiley-VCH, Weinheim, 2008, pp. 2882-2905.

[41] H. Zhao, J. Chen, Y. Sun, Div. Fuel Chem. 48 (2003) 733-734.

[42] D.I. Kondarides, Z. Zhang, X.E. Verykios, J. Catal. 176 (1998) 536-544.

[43] C.A. Rice, S.D. Worley, C.W. Curtis, J.A. Guin, A.R. Tarrer, J. Chem. Phys. 74 (1981) 6487-6497.

[44] S.S.C. Chuang, S. Debnath, J. Mol. Catal. 79 (1993) 323-334.

[45] C.D. Zeinalipour-Yazdi, A.L. Cooksy, A.M. Efstathiou, J. Phys. Chem. C 111 (2007) $13872-13878$.

[46] M.M.M. Jansen, B.E. Nieuwenhuys, D.C. Ferré, J.W. Niemantsverdriet, J. Phys Chem. C 113 (2009) 12277-12285.
[47] G. Krenn, I. Bako, R. Schennach, J. Chem. Phys. 124 (2006) 144703.

[48] K. Hadjiivanov, E. Ivanova, L. Dimitrov, H. Knözinger, J. Mol. Struct. 661-662 (2003) 459-463.

[49] C.T. Campbell, Nat. Chem. 4 (2012) 597-598.

[50] J.A. Farmer, C.T. Campbell, Science 329 (2010) 933-936.

[51] A. Bruix, J.A. Rodriguez, P.J. Ramírez, S.D. Senanayake, J. Evans, J.B. Park, D. Stacchiola, P. Liu, J. Hrbek, F. Illas, J. Am. Chem. Soc. 134 (2012) 8968-8974.

[52] J.A. Rodriguez, P. Liu, J. Hrbek, J. Evans, M. Pérez, Angew. Chem. Int. Ed. 46 (2007) 1329-1332.

[53] A. Trovarelli, Catal. Rev. Sci. Eng. 38 (1996) 439-520.

[54] G. Busca, Catal. Today 27 (1996) 457-496.

[55] Z. Say, E.I. Vovk, V.I. Bukhtiyarov, E. Ozensoy, Appl. Catal. B 142 (2013) 89-100.

[56] E. Ozensoy, D. Herling, J. Szanyi, Catal. Today 136 (2008) 46-54.

[57] F. Frola, F. Prinetto, G. Ghiotti, L. Castoldi, I. Nova, L. Lietti, P. Forzatti, Catal. Today 126 (2007) 81-89.

[58] L. Chen, S. Wang, J. Zhou, Y. Shen, Y. Zhao, X. Ma, RSC Adv. 4 (2014) 30968-30975.

[59] P. Osorio-Vargas, C.H. Campos, R.M. Navarro, J.L.G. Fierro, P. Reyes, Appl. Catal. A Gen. 505 (2015) 159-172.

[60] V. Rico-Pérez, A. Bueno-López, Appl. Sci. 4 (2014) 468-481.

[61] W.H. Weber, G.W. Graham, J.R. McBride, Phys. Rev. B 42 (1990) 10969-10975.

[62] W. Lin, A.A. Herzing, C.J. Kiely, I.E. Wachs, J. Phys. Chem. C 112 (2008) $5942-5951$.

[63] A. Trovarelli, F. Zamar, J. Llorca, Cd. Leitenburg, G. Dolcetti, J.T. Kiss, J. Catal. 169 (1997) 490-502.

[64] M.D. Rhodes, A.T. Bell, J. Catal. 233 (2005) 198-209.

[65] E.I. Ross-Medgaarden, W.V. Knowles, T. Kim, M.S. Wong, W. Zhou, C.J. Kiely, I.E. Wachs, J. Catal. 256 (2008) 108-125.

[66] Z. Say, M. Tohumeken, E. Ozensoy, Catal. Today 231 (2014) 135-144.

[67] Y. Fan, S. Cheng, H. Wang, J. Tian, S. Xie, Y. Pei, M. Qiao, B. Zong, Appl. Catal. B 217 (2017) 331-341.

[68] J.Z. Shyu, W.H. Weber, H.S. Gandhi, J. Phys. Chem. 92 (1988) 4964-4970.

[69] J. Guzman, S. Carrettin, A. Corma, J. Am. Chem. Soc. 127 (2005) 3286-3287.

[70] B.M. Reddy, A. Khan, P. Lakshmanan, M. Aouine, S. Loridant, J.-C. Volta, J. Phys. Chem. B 109 (2005) 3355-3363.

[71] S. Musić, A. Šarić, S. Popović, M. Ivanda, J. Mol. Struct. 924 (2009) 221-224.

[72] A. Filtschew, K. Hofmann, C. Hess, J. Phys. Chem. C 120 (2016) 6694-6703.

[73] C. Schilling, A. Hofmann, C. Hess, M.V. Ganduglia-Pirovano, J. Phys. Chem. C 121 (2017) 20834-20849.

[74] A. Filtschew, C. Hess, J. Phys. Chem. C 121 (2017) 19280-19287.

[75] S. Scirè, S. Minicò, C. Crisafulli, C. Satriano, A. Pistone, Appl. Catal. B 40 (2003) 43-49.

[76] M. Baldi, E. Finocchio, F. Milella, G. Busca, Appl. Catal. B 16 (1998) 43-51.

[77] J. Gao, Z. Hou, H. Lou, X. Zheng, D. Shekhawat, J.J. Spivey, D.A. Berry (Eds.), Fuel Cells: Technologies for Fuel Processing, Elsevier, Amsterdam, 2011, pp. 191-221.

[78] W. Wang, Fuel Process. Technol. 91 (2010) 1401-1408.

[79] J.A. Moulijn, A.E. van Diepen, F. Kapteijn, Appl. Catal. A Gen. 212 (2001) 3-16.

[80] W.-C. Chung, M.-B. Chang, Renew. Sustain. Energy Rev. 62 (2016) 13-31. 